\title{
Getting Incentives Right: Is Deferred Bank Executive Compensation Sufficient?
}

\author{
Sanjai Bhagat, Brian Bolton, and Roberta Romano $\dagger^{\dagger}$
}

In the wake of the global financial crisis, attention has often focused on whether incentives generated by bank executives' compensation programs led to excessive risk-taking. Post-crisis, compensation reform proposals have taken broadly three approaches: long-term deferred equity incentive compensation, mandatory bonus clawbacks upon accounting restatements and financial losses, and debt-based compensation. In earlier articles we recommended the following compensation structure for bank executives: incentive compensation should consist only of restricted stock and restricted stock options - restricted in the sense that the executive cannot sell the shares or exercise the options for two to four years after his or her last day in office. We contend that this incentive compensation package, which we term the Restricted Equity proposal, will focus bank managers' attention on the long-run and discourage them from investing in high-risk, value-destroying projects.

Equity based incentive programs such as our proposal may lose effectiveness in motivating managers to enhance shareholder value as a bank's equity value approaches zero. As a consequence, some commentators have called for pay packages linked to bank debt. We contend, however, that the more appropriate approach is to retain equity-based incentive pay and to reform bank capital structure to reduce the probability of a tail event, and hence insolvency. We advance two approaches, not necessarily exclusive, that coupled with the Restricted Equity proposal, we maintain, would incentivize bank executives to not take on projects of excessive risk: meaningful higher and simpler capital requirements and mandatory issuance of contingent convertible capital-debt that converts to equity under specified adverse states of the world. Because the optimal capital level is unknown, we further advocate

$\dagger$ Sanjai Bhagat is Provost Professor of Finance, University of Colorado, Boulder Leeds College of Business. Brian Bolton is Assistant Professor of Finance, Portland State School of Business Administration. Roberta Romano is Sterling Professor, Yale Law School, and fellow, NBER and ECGI. This article draws upon three prior articles, which stress different aspects of the restricted equity executive incentive compensation proposal: Sanjai Bhagat \& Roberta Romano, Reforming Executive Compensation: Focusing and Committing to the Long-Term, 26 YALE J. REG. 359 (2009); Sanjai Bhagat \& Roberta Romano, Reforming Executive Compensation: Simplicity, Transparency and Committing to the Long-term, 7 EUR. CO. \& FIN. L. REV. 273 (2010); Sanjai Bhagat \& Roberta Romano, Reforming Executive Compensation for the Long-term, in RESEARCH HANDBOOK ON EXECUTIVE PAY (Randall S. Thomas \& Jennifer G. Hill eds., 2012). Passages from the articles are reused with permission. We would like to thank Henry Hansmann, Conference participants and participants at Arizona State and Yale law school faculty workshops for helpful comments. 
facilitating regulatory diversity within the international financial regulatory regime, to generate information concerning what level and form of capital works best, which would improve the quality of decision-making and the resiliency of the global financial system.

I. Introduction

II. Pre-crisis Executive Compensation and Misaligned Incentives.

III. Mitigating Excessive Risk-taking by Bank Employees ......................... 536

A. The Restricted Equity Proposal ...............................................556

B. Comparison to Regulatory Initiatives ...........................................544

C. Comparison to Debt-Based Compensation Proposals.................. 548

IV. Capital Structure and Executive Compensation ................................ 552

A. Raising and Simplifying Bank-Capital Requirements ................... 552

B. Requiring Capital in the Form of Contingent Convertible Debt.... 559

$C$. Introducing Diversity and Experimentation into Financial Regulation .................................................................... 561

V. Conclusion

\section{Introduction}

In the wake of the global financial crisis, attention has often focused on whether incentives generated by bank executives' compensation programs led to excessive risk-taking. Post-crisis compensation reform proposals have, broadly speaking, taken one of three approaches: long-term deferred equity incentive compensation, mandatory bonus clawbacks upon accounting restatements or financial losses, and debt-based compensation. Governments worldwide have, in particular, regulated bank executives' compensation by requiring deferral of incentive compensation, mandating clawbacks, and in some instances, even restricting compensation amounts. ${ }^{1}$ In earlier articles we recommended the following compensation structure for bank executives, with which these government initiatives are only partially consistent: incentive compensation should consist only of restricted stock and restricted stock

1. In 2009, the Group of Twenty ("G-20") adopted principles on banks' incentive compensation emphasizing deferral and clawbacks, FIN. STABILITY FORUM, PRINCIPLES FOR SOUND COMPENSATION PRACTICES (2009), http://www.financialstabilityboard.org/publications /r_0904b.pdf. These principles were incorporated into the supervisory guidelines of the Basel Committee on Banking Supervision and implemented in the United States and European Union ("EU"). The G-20 consists of the finance ministers and central bankers of 19 industrial and emerging market countries plus the European Union. The Basel Committee was created by the central bankers of the G-10 nations to coordinate supervisory standards, with membership expanded to the G-20 in 2009. Most recently, the EU has restricted bankers' incentive compensation to $100 \%$ of total fixed pay, with some exceptions for shareholder-approved packages. For a summary of the legislation, which is known as Capital Requirements Directive (CRD) IV, see Client Memorandum, Davis Polk \& Wardwell LLP, Recent European Compensation Developments: Financial Institutions and Beyond (Apr. 23, 2013), http://www.davispolk.com/sites/default/files/files/Publication/f3691634-6c28-4c9a-bbbd-bba7a8ad07e0/ Preview/PublicationAttachment/2679f2aa-634f-4093-9a35-c44b9c 147edb/04.23.12.European.Compens ation.pdf. 
options-restricted in the sense that the executive cannot sell the shares or exercise the options for two to four years after his or her last day in office. ${ }^{2} \mathrm{We}$ contend that such an incentive compensation package will focus bank management's attention on the long-run and discourage investment in highrisk, value-destroying projects.

Equity-based incentive programs such as our proposal may lose effectiveness in motivating managers to reduce excessive risk-taking as a bank's equity value approaches zero. There is a moral hazard or agency cost of debt in this context arising from shareholders' potential preference to take extreme risks when close to insolvency: shareholders would gain from a lowprobability, large positive outcome, while limited liability leaves the losses, should (with greater probability) the gamble fail, on creditors. The moral hazard problem when equity value approaches zero may well be more severe for banks, as their creditors have less interest in monitoring against risk-taking activity because the government not only stands behind retail depositors, but also often bails out other creditors as well. ${ }^{3}$ Properly aligning management's incentives in this context therefore calls for attentiveness to the interaction among different pieces of the regulatory landscape of financial institutions, whereas compensation reform is conventionally analyzed in isolation. ${ }^{4}$

Incentive compensation reform proposals that advocate linking bank executives' compensation to debt are directed at this moral hazard concern, although the tendency for broad-based creditor bailouts complicates the efficacy of such an approach, compared to using debt-based compensation to address the phenomenon in nonfinancial firms. We contend that equity-based incentive pay is still decisively preferable to debt-based pay in motivating managers to maximize bank value. In our judgment, the appropriate approach to mitigate the insolvency-related moral hazard problem is to combine a properly structured equity incentive scheme with a capital structure that contains considerably more equity than currently required, directly or through

2. Sanjai Bhagat \& Roberta Romano, Reforming Executive Compensation: Focusing and Committing to the Long-term, 26 YALE J. REG. 359 (2009); Sanjai Bhagat \& Roberta Romano, Reforming Executive Compensation: Simplicity, Transparency and Committing to the Longterm, 7 EUR. Co. \& FIN. L. REV. 273 (2010) [hereinafter "Bhagat \& Romano, Simplicity."]; Sanjai Bhagat \& Roberta Romano, Reforming Executive Compensation for the Long-term, in RESEARCH HANDBOOK ON EXECUTIVE PAY (Randall S. Thomas \& Jennifer G. Hill eds., 2012) [hereinafter "BHAGAT \& ROMANO, LONG-TERM"]. There are subtle differences across the three versions of our proposal as we had more time to ponder, elaborate and tinker with our proposal, and respond to critiques and alternative proposals.

3. In the global financial crisis, for example, the U.S. government protected creditors and even shareholders in the largest financial institutions, such as the insolvent Citigroup, by bolstering firms with cash infusions for preferred stockholdings, although it did not bail out shareholders of other large institutions that failed, such as Washington Mutual.

4. For one of the few formal models considering the interaction of different regulatory tools-capital requirements, supervision, and market discipline-which provides counterintuitive results, such as supervision and market discipline are complements not supplements and that under restrictive conditions capital requirements can be reduced if subordinated debt is mandated, see JEAN-CHARLES ROCHET, WHY ARE THERE SO MANY BANKING CRISES? 258-74 (2008). 
the use of contingent convertible debt ("CoCos"), debt that converts into equity under specified adverse states of the world.

The causes of the global financial crisis of 2008 will, no doubt, be analyzed and debated by economists for generations. Factors that have been identified as contributing to this crisis range from misguided government policies to an absence of market discipline of financial institutions, which further had inadequate or flawed risk-monitoring and incentive systems. ${ }^{5}$ Such government policies include monetary policy (low interest rates by the Federal Reserve) and the promotion of subprime risk-taking by government-sponsored entities dominating the residential mortgage market so as to increase home ownership by those who could not otherwise afford it. ${ }^{6}$ Sources of inadequate market discipline include private parties' reliance on credit rating agencies. Internal organizational factors contributing to the crisis include business strategies dependent on high leverage and short-term financing of long-term assets, reliance on risk and valuation models with grossly unrealistic assumptions, and poorly-designed incentive compensation, factors whose flaws were exacerbated by ineffective prudential regulation and global capital requirements in the Basel Accords that favored securitized subprime loans over more conventional assets. These factors, taken as a whole, encouraged what, with the benefit of hindsight, can be characterized as excessive risk-taking.

Our focus is incentive compensation not because we believe that was the most important contributing factor to the crisis. We doubt that to be the case. Rather, it is our focus because incentive compensation is an area in which legislators and banking regulators worldwide have implemented regulatory reforms, even as the appropriateness of pay structures is still a matter of contentious debate. It is also a factor within the control of bank managers and shareholders, so that the private sector could undertake changes, in a direction that we consider more beneficial than the regulatory initiatives, without needing to harness coordinated government action.

Although we believe that the Restricted Equity proposal is superior to the approach regulators have taken to compensation, and that regulators would do well to consider replacing what they have done with our approach, our proposal is directed to boards of directors because we recognize that it is unrealistic to expect regulators to substitute it for their recently-adopted initiatives, especially at an international level, given the arduous process of obtaining multinational consensus. The complementary proposal for increased capital requirements could also be implemented by financial institutions without regulatory action. But because deposit insurance and creditor bailouts have resulted in the market not requiring banks to hold substantially higher capital than current levels, short

5. See, e.g., Charles Calomiris, The Subprime Turmoil: What's Old, What's New, and What's Next, 15 J. STRUCTURED FIN., Spring 2009, at 6; Douglas Diamond and Raghuram Rajan, The Credit Crisis: Conjectures About Causes and Remedies, 99 AMER. ECON. REV. 606 (2009); KENNETH FRENCH ET AL., THE SQUAM LAKE REPORT 28-29, 75-76 (2010).

6. See, e.g., PETER WAllison, BAD History, WORSE POLICY 116-132 (2013). 
of the market believing that post-crisis resolution initiatives will be effective at limiting future bailouts, we think it improbable that the capital reform component of our proposal would be voluntarily adopted. Although the Restricted Equity proposal's effectiveness would be further optimized when combined with an increase in capital requirements, it does not require such a regulatory change. For it would reduce the probability that a bank will near insolvency, the zone in which the need for increased capital requirements is most critical, and in the typical solvent zone of bank operations it will provide more appropriate risk-taking incentives than debt-oriented compensation proposals.

The article is organized as follows. The next Part briefly overviews precrisis compensation packages, how they might have led to misaligned incentives, and evidence of such misalignment. We then review our restricted stock proposal, which we maintain will mitigate bank managers' excess risktaking incentives, and why we think it is preferable to both what governments have done and debt-based compensation proposals. We present our approach to bank capitalization reform, which is complementary to the incentive compensation proposal, in the last section. In addition to advocating that banks hold higher capital than presently required, we consider an alternative solution in which banks would issue contingent debt in lieu of higher capital requirements. In our judgment, combining the Restricted Equity proposal with capital structure reform is a better mechanism for reducing the probability of banks taking on excessive risk than existing regulatory compensation initiatives or fashioning more complicated debt-based compensation plans.

\section{Pre-crisis Executive Compensation and Misaligned Incentives}

Pre-crisis executive incentive compensation packages did consist of an equity portion that was deferred, typically with a 2-5 year vesting requirement, most often granted in relation to meeting annual performance targets. ${ }^{7}$ But

7. Lehman Brothers, for example, in 2005, paid executive officers with both cash and equity incentive compensation under its "Short Term Executive Compensation Plan," as well as stock options, with base pay making up a small portion of total compensation. Lehman Bros. Holdings Inc., Definitive Proxy Statement (Form DEF 14A) 16 (Feb. 27, 2006). The equity component was in the form of restricted stock units (RSU) of which $35 \%$ vested over 3 years and the remainder over 5 years, subject to certain forfeiture provisions. Id. at 17 . The stock options could be exercised in two years if the stock price increased by $28 \%$, otherwise they could not be exercised for $4-1 / 2$ years, with an expiration date of 5 years. In addition to the annual incentive plan, there was also a long-term incentive plan that awarded performance stock units that converted to transferrable shares vesting on a staggered basis over three years. Id. That year its CEO received $58 \%$ of his total compensation in equity, but of the $42 \%$ in cash compensation, virtually all was a cash bonus that vested automatically, and that bonus, $\$ 13.75$ million, was roughly equal to the value of his awarded RSUs (\$14.9 million). Id. at 19. In 2007, the CEO received a much larger percentage in equity than cash, with the cash bonus equal to only slightly more than $10 \%$ of his total compensation, and only about $1 / 10$ of awarded RSUs. Lehman Bros. Holdings Inc., Definitive Proxy Statement (Form DEF 14A) 26-27 (March 5, 2008). The firm also paid non-executive employees annual cash and equity bonuses, with the latter ranging from $1-50 \%$ of total compensation, the percentage increasing as total compensation increased. Lehman Bros. Holdings Inc., 
many lower-level employees, whose activities could generate disastrous losses and who were highly paid, such as, individuals trading for the bank's proprietary account, received straight cash bonuses at year-end, pegged to the booked profits of their trades (even though the trades were open and initial profits could, as it turned out in the crisis, generate crushing losses). ${ }^{8}$ Further, banks' risk officers were often paid low or flat salaries compared to other executives and their authority and ability to control risk-taking varied considerably across institutions. ${ }^{9}$ These organizational incentives no doubt worked at cross purposes with senior executives' ability to manage their firms' risk and performance as the global crisis unfolded.

How might the incentives generated by incentive compensation programs in banks lead to excessive risk-taking and benefit executives and traders at the expense of long-term shareholders? Consider a stylized example, an investment project or trading strategy that in any given year can lead to six cash flow outcomes with equal probability, five of which are a positive $\$ 500$ million and the sixth is a random loss that increases over time (until a certain future period) denoted by the following time-varying random variable:

Sixth outcome $=-\$(0.5+\varepsilon)$ billion; for $t$ between years $t_{1}$ and $t_{2}$, and

Sixth outcome $=-\$(0.5+\varepsilon)(\mathrm{t})$ billion; for $\mathrm{t}$ greater than $\mathrm{t}_{2}$ years,

where, $\varepsilon$ is an error term with mean zero and standard deviation $\sigma$.

Given the above payoffs, the expected cash flow from the investment project or trading strategy is positive for the first few years. However, after these initial years the expected cash flow from the investment project or trading strategy turns negative. Additionally, the life of the project is such that its net present value ("NPV) is negative. ${ }^{10}$ The probability, the magnitude of the cash

Definitive Additional Materials (Form DEFA14A, (March 30, 2007) (describing the company's Equity Award Program because shareholders were asked to approve an amendment to the plan).

8. See, e.g., Simone M. Sepe and Charles K. Whitehead, Risky Business: Competition, Compensation and Risk-taking, 100 CORNELL L. REV (forthcoming, 2015).

9. Andrew Ellul and Vijay Yerramilli have created a risk management index for bank holding companies, measuring the strength and independence of the risk management function. Their index includes both individual and organization features, such as whether the chief risk officer was an executive officer of the holding company or among the five highest compensated employees (true in only $20 \%$ of the firm-year observations, but with increasing frequency, e.g. $43.5 \%$ in 2009), and whether the board risk management committee had an independent director with banking or finance expertise or met more frequently than average over a year. The index measure varies considerably across firms, as do the individual components of the index. Firms that had a higher index (better risk management) precrisis had lower tail risk (performed better) during the financial crisis. Andrew Ellul \& Vijay Yerramilli, Stronger Risk Controls, Lower Risk: Evidence from U.S. Bank Holding Companies, 68 J. FIN. 1757 (2013).

10. Simplified cash flows and probabilities have been used for illustrative purposes to clarify the intuition of the analysis. The project's expected cash flows, as in the numerical illustration, need only have the pattern that early on there are positive expected cash flows and later on they turn negative, so that the net present value is negative. In this stylized example, the expected cash flows would be positive for the first four years, zero in year five, and negative for all subsequent years. Because the six outcomes have equal probability, in years 1 and 2 the cash flows expected by both the bank executives and the investing public are $(\$ 500$ million $\times 5 / 6)+(-\$ 500$ million $\times 1 / 6)=\$ 333$ million in each year. For the investing public, $\$ 333$ million is the expected cash flow in every year because they are not aware of the risk of increasing losses over time associated with Outcome 6 . However, the bank 
flows of the six outcomes, and the life of the project are known only to the bank executives. Given the information available to or processed by the investing public, were the project or strategy announced in advance, they would not perceive that the sixth outcome's loss is increasing over time, and therefore the stock market would have a different--positive-valuation of the trading strategy from bank management, as indicated in Table 1.

Table 1. Example 1: Expected Cash Flows (Executives Know True Probabilities)

\begin{tabular}{|l|l|l|}
\hline \multirow{2}{*}{} & \multicolumn{2}{|c|}{ Expected Cash Flows } \\
\cline { 2 - 3 } & \multicolumn{1}{|c|}{ By Bank Executives } & \multicolumn{1}{|c|}{ By Investing Public } \\
\hline Outcome 1: & $+\$ 500$ million & $+\$ 500$ million \\
\hline Outcome 2: & $+\$ 500$ million & $+\$ 500$ million \\
\hline Outcome 3: & $+\$ 500$ million & $+\$ 500$ million \\
\hline Outcome 4: & $+\$ 500$ million & $+\$ 500$ million \\
\hline Outcome 5: & $+\$ 500$ million & $+\$ 500$ million \\
\hline & $-\$(0.5+\varepsilon)$ billion \\
Outcome 6: & $\begin{array}{l}\mathrm{t} \text { between years } \mathrm{t}_{1} \text { and } \mathrm{t}_{2 ;} \\
\text { ( } 5(0.5+\varepsilon)(\mathrm{t}) \text { billion } \\
\text { for } \mathrm{t} \text { greater than } \mathrm{t}_{2} \text { years }\end{array}$ & $-\$ 500$ million \\
\hline Project NPV & Negative & Positive \\
\hline Investment Decision & Do Not Invest & Invest \\
\hline
\end{tabular}

How should the individual decision-maker-a bank executive or traderrespond to the above investment project or trading strategy if he or she were acting in the interest of the long-term shareholders? As indicated in Table 1, because the NPV of the investment project/trading strategy is negative, this investment project or trading strategy should be rejected.

executives are aware that these potential losses increase over time, beginning in year 3 . Therefore, for year 3, the bank executives' expected cash flow is $(\$ 500$ million $\times 5 / 6)+(-\$ 500$ million $\times 3 \times 1 / 6)=$ $\$ 167$ million. For year 4 , the bank executives' expected cash flow is $(\$ 500$ million $\times 5 / 6)+(-\$ 500$ million $\times 4 \times 1 / 6)=\$ 83$ million. By year 6 , the expected cash flow is $-\$ 83$ million; by year 12 , the expected cash flow is $-\$ 583$ million. Taking the present value of this series of 12 annual cash flows using a $10 \%$ discount rate yields an expected value of the project of $-\$ 152$ million based on what the bank executives know. Because the investing public believes that the expected cash flows are $\$ 333$ million each year, their expected project value over the same 12 years and with the same $10 \%$ discount rate is $\$ 2.27$ billion. Under the assumption of a $10 \%$ discount rate, the NPV is negative if the cash flows last for twelve years or longer, which is not an unreasonable time horizon for bank investments. 
But will the individual undertake the investment project or trading strategy? To answer this question, we have to consider the compensation structure. For convenience, we will refer to the decision-maker in the example as the bank CEO. Assume the CEO owns a significant number of bank shares. Furthermore, these shares are unrestricted, that is, they have either vested or have no vesting requirements. If the bank adopts the above trading strategy, and given the belief of the stock market about this investment project or trading strategy, the bank's share price will increase. In any given year there is a very high probability $(5 / 6=83 \%)$ that the trading strategy will generate a very large positive cash flow of $\$ 500$ million. If the realization from the trading strategy is one of the positive cash flow outcomes (and there is an $83 \%$ probability of this), the bank share price will rise, the bank in response will award incentive compensation to key employees, including the CEO, and the CEO can then liquidate a significant part of her equity holdings at a profit. ${ }^{11}$

To be sure, in this stylized example, the bank CEO knows that the expected cash flow from this trading strategy will be negative in the later years. There is also some probability ( $17 \%$ in this example) that in any given year the trading strategy will lead to a negative cash flow outcome. Additionally, the magnitude of the negative outcome increases over time. What then? In the textbook corporate finance paradigm, the bank's share price will decline, and, depending on the bank's equity capitalization, the bank will be insolvent or close to insolvent, and subject to corrective action or government takeover. ${ }^{12}$ This insolvency or close-to-insolvency scenario will certainly have a significantly negative impact on the value of the CEO's bank stockholdings. However, if during the first few years of this trading strategy the cash flow outcomes have been positive and the CEO has liquidated a significant amount of shares, then despite the CEO's experiencing large losses on her remaining holdings as the bank faces large losses or possibly insolvency in a future year, the CEO's net payoff from employment in the bank (salary, bonus, plus proceeds from sale of stock) in the earlier years, may well still be positive and even possibly substantial. In addition, during the global financial crisis, governments did not permit the largest banks to fail, and so a rational CEO may

11.

In an efficient market, the share price would rise by the expected value of the trading strategy were it announced in advance, because it is a positive NPV project according to the publicly available information. Accordingly, the stock price would not rise that much upon the subsequently realized positive cash flows, affecting the matching of the size of the payout of an incentive compensation system based on annual stock price increases. For the purpose of simplifying the example, we ignore that timing issue by making the plausible assumption that the trading strategy is not public information when adopted and the public valuation (stock price) depends only on the realized cash flow each year.

12. Commercial banks are not permitted to go bankrupt in the United States: insolvent banks are taken over by banking regulators, and the assets and depositor liabilities are sold to another bank or liquidated. 
have a further impetus to take on the risk: if it is a "too big to fail" bank, even his equity may be preserved when the bank is bailed out. ${ }^{13}$

It is not necessary to assume, as does our stylized example, that bank CEOs intentionally undertook or encouraged employees to undertake, negative NPV projects or trading strategies, to suggest that pre-crisis compensation packages could have produced misaligned incentives. An alternative scenario that could produce a similarly distorted investment outcome would occur if a CEO misperceives the probabilities of a project's negative cash flows, rendering a value-destroying project appear to be value creating. If, for instance, executives have a rosier picture of a project's outcomes than warranted because, say, they are over-confident in their abilities to manage it, or they are overly optimistic about the future, then we do not have to posit managers who intentionally seek to rip off shareholders. We would only be acknowledging human nature "as we know it," that individuals quite often believe they are more talented than most and therefore are overly confident and more optimistic regarding the success of their endeavors than the objective situation would warrant (in this instance, the executive is overconfident with regard to project selection or trading ability, or the effectiveness of internal risk management. and hence overly optimistic about projected cash flows). ${ }^{14}$ Precrisis compensation packages could again produce misaligned incentives as they could exacerbate the impact of optimism by not inducing executives to focus diligently on estimating more accurately all of a project's cash flows or the risks associated with those cash flows. A similar misalignment could occur without behavioral assumptions of overconfidence and optimism if the CEO miscalculates a project's expected outcomes due to inadequate internal organization information flows or risk management practices, or simply sloppiness (e.g., lack of effort).

Consider the following emendation of our earlier stylized example, in which the probabilities of the six possible outcomes are not equal. In addition, the bank executives do not know the true cash flows and probabilities. Because the executives' expected probabilities will differ from the actual probabilities,

13. We think that it is unlikely that post-crisis reforms have eliminated "too big to fail," as ex post it is typically more efficient to bail out an institution than let it fail. See, e.g., RoCHET, supra note 4, at 31. Even if it were to be more efficient to let the institution fail, government officials will tend to not want to find out what would happen were they to do so, particularly in the aftermath of the impact of Lehman Brothers' bankruptcy on the market.

14. The behavioral psychology literature finds that individuals are overly selfconfident and optimistic, often referred to as the "better than average effect." For a corporate finance application in which optimistic managers perceive negative NPV projects as positive NPV projects (they overestimate the probability of positive cash flows and thereby underestimate the probability of losses), which fits with empirical patterns of corporate financing and free cash flow usage, see J.B. Heaton, Managerial Optimism and Corporate Finance, 31 FIN. MGT., Summer 2002, at 33. For the classic review of behavioral finance (the application of the psychological literature to financial decisionmaking), see Werner F.M. DeBondt \& Richard H. Thaler, Financial Decision-making in Markets and Firms: A Behavioral Perspective, in 9 FINANCE, HANDBOOK IN OPERATIONS RESEARCH AND MANAGEMENT SCIENCE (Robert Jarrow et al. eds., 1996). 
some investment decisions will be made that should not have been made. ${ }^{15}$ As indicated in Table 2, this occurs in the example because the executives perceive the project to have a positive NPV, when it actually has a negative NPV. This is because the managers' calculation perceives the possible loss as more remote, as well as occurring much further in the future (when they would expect, no doubt, either that the project would no longer be pursued or they would no longer be at the firm) than is actually the case. ${ }^{16}$

Of course, these cash flows and probabilities are hypothetical; the key is that there can be non-trivial differences between expected and actual future outcomes. These differences can drive the investment decisions of the bank, which can become problematic if the incentives of bank executives and the shareholders are not properly aligned. If, as in the earlier example, the executives' incentive compensation can be liquidated in the near term, then, again, they might be able to benefit more on their stock sales than they lose on their equity holdings when the project's negative value is realized after the initial successes. The point of this second stylized example is that even if executives do not seek intentionally to mislead shareholders, but for a variety of reasons, including overconfidence, optimism, poor internal organization, or sloppy thinking, they misjudge the outcome, they could be rewarded for doing so due to short-term incentive compensation. Because their compensation depends solely on the current (realized) year's cash flow, they will have little incentive to estimate more diligently the probabilities of the project's continuing cash flows. A longer-horizon incentive compensation structure

15 .

As with the original example, simplified cash flows and probabilities have been used for illustrative purposes. The project's expected cash flows need only be different from the actual NPV. In this example, this difference is caused by the differences between the expected and actual probabilities of outcomes. But the difference could be caused by other errors in expectation, such as the executives not accurately forecasting the cash flows or the extent of the increase of the potential loss in the sixth outcome over time. In addition, as before, the public is not better informed than the bank insiders and also perceives the project's NPV as positive; for the purpose of the example, it does not matter whether or not the reason for the public's miscalculation is that it makes the same estimation error as the managers.

16. Based on the above stylized cash flow and probability assumptions, the expected cash flows do not become negative until the tenth year of the project. In years 1 and 2 the bank managers expect the cash flows to be $(\$ 500$ million $\times 90 \%)+(-\$ 500$ million $\times 10 \%)=\$ 400$ million each year. In year 3, when the loss in Outcome 6 increases, the managers' expected cash flows are ( $\$ 500$ million $\times 90 \%)+(-\$ 500$ million $\times 3 \times 10 \%)=\$ 300$ million. For year 4 , the expected cash flows are $\$ 250$ million; by year 10 the expected cash flows are $-\$ 50$ million and by year 30 the expected cash flows have decreased to $-\$ 1,050$ million. Taking the present value of these 30 years of cash flows, using a $10 \%$ discount rate, the expected present value becomes $-\$ 42$ million in the $30^{\text {th }}$ year. If the project lasts less than 30 years, it has a positive expected value. However, these expectations are much different from the actual probabilities. In years 1 and 2 , the cash flows associated with the actual probabilities are $(\$ 500$ million $\times 75 \%)+(-\$ 500$ million $\times 25 \%)=\$ 250$ million, considerably lower than the executives' expected value of $\$ 400$ million. By year 10 , the cash flows associated with the actual probability are $-\$ 875$ million and they are $-\$ 3,375$ million by year 30 . Taking the present value of the cash flows over the 30 year period yields an actual value of $-\$ 7.2$ billion. The actual value becomes negative much more quickly than the executives expect: after only seven years, the actual present value is $-\$ 275$ million, while the executives expect the present value through seven years to be a positive $\$ 1,350$ million. The actual cash flows become negative in the fourth year of the project, and, again assuming a $10 \%$ discount rate, the NPV becomes negative if the cash flows persist for seven years. 
should focus their attention on obtaining more accurate estimates of a project's expected future cash flows. Moreover, they could no longer benefit at the shareholders' expense from a project whose short- and long-term cash flows were so disparate, because not being able to sell their shares or receive cash bonuses in the early years of the project's life, they will bear the same ultimate net loss on their holdings as the outside long-term investors. ${ }^{17}$

Table 2. Example 2: Expected Cash Flows (Executives Do Not Know True Probabilities)

\begin{tabular}{|c|c|c|c|}
\hline Expected & Cash Flows by Bank Executives & Expected & Actual \\
\hline Outcome 1: & +\$500 million & $18 \%$ & $15 \%$ \\
\hline Outcome 2: & $+\$ 500$ million & $18 \%$ & $15 \%$ \\
\hline Outcome 3: & $+\$ 500$ million & $18 \%$ & $15 \%$ \\
\hline Outcome 4: & $+\$ 500$ million & $18 \%$ & $15 \%$ \\
\hline Outcome 5: & $+\$ 500$ million & $18 \%$ & $15 \%$ \\
\hline Outcome 6: & $\begin{array}{l}-\$(0.5+\varepsilon) \text { billion for } t \text { between } \\
\text { years } t_{1} \text { and } t_{2} \\
-\$(0.5+\varepsilon)(t) \text { billion; for } t \text { greater } \\
\text { than } t_{2} \text { years }\end{array}$ & $10 \%$ & $25 \%$ \\
\hline Project NPV & & Positive & Negative \\
\hline Investment I & ecision & Invest & Do Not Invest \\
\hline
\end{tabular}

Notwithstanding the intuitive logic of the impact of incentives as conveyed by these stylized examples, the literature on the impact of executive compensation packages on banks' performance during the crisis is ambiguous. Rüdiger Fahlenbrach and René Stulz find no evidence that U.S. banks' performance in the crisis was correlated with either the CEO's having higher option pay or receiving larger cash bonuses (i.e., what they consider short-term

17. Bank employees might nonetheless adopt negative NPV (albeit short-term positive cash-flow) investments in response to pressure from shareholders with short-term investment horizons. E.g., John R. Graham et al., Value Destruction and Financial Reporting Decisions, 62 FIN. ANALYSTS J. 27 (2006); Eva Liljeblom \& Mika Vaihekoski, Who Creates Short-Term Pressure? An Analysis of Firms with Different Ownership Structures, 59 FINNISH J. BUS. ECON. 239 (2010). But such a possibility is only a further reason in support of the Restricted Equity proposal, as it will ensure that incentive compensation has a countervailing, rather than a magnifying, impact on decisions. 
incentive compensation) or owning more equity, and some evidence that performance was worse for CEOs whose incentives were better aligned with shareholders. ${ }^{18}$ They further report that bank CEOs suffered substantial losses on their equity holdings and stock sales during the crisis, in support of the view that bank executives were acting in shareholders' interest regarding pre-crisis risk-taking. ${ }^{19}$ Felix Suntheim also finds no relation between any type of incentive compensation and stock performance, while accounting performance was adversely affected by short-term incentives but not equity ownership. ${ }^{20}$

However, other studies find that banks whose executives had higher shortterm compensation, or a higher proportion of equity compensation, took on more risk and performed more poorly during the crisis. ${ }^{21}$ In addition, the research of two of us, Bhagat and Bolton, by contrast to that of Fahlenbrach and Stulz, finds that the pre-crisis level of risk of the largest banks that received government support under the troubled asset relief program ("TARP") was

18. Rüdiger Fahlenbrach \& René M. Stulz, Bank CEO Incentives and the Credit Crisis, 99 J. FIN. ECON. 11 (2011) (assessing the performance of 98 U.S. banks over July 2007December 2008, and finding no evidence that banks with higher CEO option pay performed worse and no evidence that those with higher CEO equity ownership performed better, during the crisis, using both stock and accounting measures of performance). They measure CEOs' alignment with shareholder interests by how sensitive the CEO's stock and option portfolio is to changes in the bank's stock value. The findings were the same for banks that received government assistance under the TARP program and those that did not. Id. at 22. Esa Jokivuolle and Jussi Keppo use a compensation database that, in contrast to Fahlenbrach and Stulz's data, permits them to identify the actual duration of compensation bonuses, allowing fine distinctions regarding how short-term the CEOs' incentives were. Esa Jokivuolle \& Jussi Keppo, Bankers' Compensation: Sprint Swimming in Short Bonus Pools? (Bank of Finland Research Discussion Paper No. 2-2014, 2014) (analyzing the impact of CEO bonus compensation in 2006 for 86 banks on their stock performance during crisis years 2007-08). They find that CEOs with shorter term bonuses (which they classify as incentivizing increased risk-taking) do have worse stock performance during the crisis, and when they restrict the analysis to the $1 / 3$ of banks that paid any bonuses, the effect is stronger. But the effect becomes insignificant once the model controls for leverage, among other variables. $I d$. at 16-17.

19. Fahlenbrach \& Stulz, supra note 18 , at 23 . The CEOs averaged sales of $2 \%$ of their holdings per quarter during 2007-08, except during the quarter of Lehman Brothers' banknuptcy, when they sold a much larger (approximately 10\%) of their holdings. Combining the sales data with equity and option grants over the period, they state that CEO ownership stayed around the same throughout.

20. Felix Suntheim, Managerial Compensation in the Financial Service Industry (Aug. 27, 2010) (unpublished manuscript), http://ssm.com/abstract=1592163 (examining CEO compensation at 77 banks in 18 countries, and finding form of compensation, equity incentive, cash bonus or otherwise, has no impact on equity retums during the 2007-08 financial crisis, but accounting performance was higher for banks whose CEOs held more equity and lower for banks whose CEOs had greater incentive pay, either short-term bonuses or option-based compensation).

21. Sudhakar Balachandran, Bruce Kogut \& Hitesh Harnal, The Probability of Default, Excessive Risk, and Executive Compensation: A Study of Financial Services Firms from 1995 to 200834 (May, 2010) (unpublished manuscript), http://ssm.com/astract=1914542 (examining compensation at 117 U.S. financial firms over 1995-2008 and interpreting finding financial firms whose executives had a higher proportion of equity compensation had higher risk, measured by the probability of default, during the crisis as indicating "managers were over-incentivized to take on excessive risk"); Sugato Bhattacharyya \& Amiyatosh Pumanandam, Risk-taking by Banks: What Did We Know and When Did We Know It? (Nov. 18, 2011) (unpublished manuscript), http://ssm.com/abstract=1619472 (studying sample of US banks, ranging between 233-278 over 2000-06 and finding banks whose CEOs' compensation had higher sensitivity to short-term earnings experienced higher mortgage default rates in the crisis, and interpreting findings as consistent with CEOs assuming risk to boost short term earnings). 
much higher than that of banks that did not receive such assistance, and that executives of those TARP recipients sold much more of their common stock holdings pre-crisis than executives of the non-TARP recipient banks. ${ }^{22}$ Because those bank executives were able to realize a substantial amount on their equity by sales in the pre-crisis period, compared to the large losses the executives experienced on their equity stake during the crisis, they suggest that compensation incentives led to excessive risk-taking. ${ }^{23}$

Rather than study executive compensation incentives, Viral Acharya, et al., investigate bank holding company performance and non-executive compensation. They find that firms whose non-executives' pre-crisis compensation was sensitive only to increases in revenue, took higher (excessive) risk and consequently performed more poorly during the financial crisis, than firms whose non-executive employees were not so incentivized. ${ }^{24}$ As they interpret the data, "the more sensitive non-executive compensation policies to short-term bank performance, the higher the incentives of middlelevel managers to increase the volume of bank activities at the expense of the quality of the acquired positions," and this risk-taking in the crisis resulted in significant declines in firm value. ${ }^{25}$ Their finding is consistent with anecdotal instances of lower-level employees' trading activities producing staggering losses, such as J.P. Morgan's "London whale" in 2012 or Barings Bank's Nick Leeson in the early 1990s. It also tracks the contention in the literature, with

22. Sanjai Bhagat \& Brian Bolton, Financial Crises and Bank Executive Incentive Compensation, 25 J. CORP. FIN. 313 (2014) (comparing risk-taking-as measured by the bank's Z-score, a measure of proximity to insolvency, asset write-downs, amount of capital and whether it borrows from government bailout programs-shareholder retums and CEO stock transactions and compensation of 14 large institutions that received TARP support to those of 37 non-TARP recipient banks over 2000-08, and finding TARP recipients had greater risk and more sales transactions). The TARP sample includes some firms that were not recipients, such as Lehman Brothers, as it was by then bankrupt, and some non-banks, such as AIG, that did receive TARP funds. The CEOs' net trading gains were greater than the value of their stock losses at half of the 14 TARP firms. Id. at 324.

23. This conclusion is therefore distinctly different from that of Fahlenbach \& Stulz, supra note 18. In Fahlenbach and Stulz's view, bank CEOs and senior executives could not or did not foresee the extreme risk of some of the bank's investment and trading strategies and the poor performance of these banks during the crisis is attributable to an extreme negative realization of the high risk nature of their investment and trading strategy. Their perspective can be analogized to the bank executives' expected probabilities of cash flows in our second stylized example, summarized in Table 2, being equal to the actual probabilities. But even if Fahlenbach and Stulz's characterization of eventsby disregarding pre-crisis stock transactions-is accurate, a proposition that we do not concede, it does not follow that the pre-crisis compensation structure was optimal and cannot be improved upon to reduce the probability of accepting investments that have large negative tail events.

24. Viral Acharya et al., Non-Executive Incentives and Bank Risk-Taking (Jan. 2014) (unpublished manuscript), http://fic.wharton.upenn.edu/fic/papers/13/13-18.pdf (finding, from a sample of 77 banks, that (i) in pre-crisis years 2003-06 non-executive compensation incentives were more sensitive to revenues than quality or sustainability of earnings; (ii) the more sensitive nonexecutive compensation policies are to short-term bank performance (proxied by how firms readjust total cash and stock compensation with variations in performance), the higher the risk taken by banks on a variety of measures-aggregate risk, tail risk, implied volatility of stock returns and Z-score-during the crisis years of 2007-09; and (iii) incentive-induced excessive risk-taking was associated with significant declines in firm value during the crisis).

25. Id. at 4 . 
which we concur, as our earlier compensation reform proposals noted, that focusing solely on executive compensation incentives is not sufficient to control excessive risk-taking. ${ }^{26}$

\section{Mitigating Excessive Risk-taking by Bank Employees}

This section introduces our proposal regarding how we would refashion bank incentive compensation to reduce the possibility that executives and other employees will undertake excessively risky and value-destroying trading or operating strategies. We then compare our proposal to the approach taken by legislatures and bank regulators and to the class of proposals advocating debtbased, rather than equity-based, compensation.

\section{A. The Restricted Equity Proposal}

In a series of articles, two of us advanced a proposal for reforming bank incentive compensation. ${ }^{27}$ We proposed that the incentive compensation of executives and individuals whose decisions may substantially impact the bank, such as proprietary traders or sellers of structured products, should consist only of restricted equity (restricted stock and restricted stock options)-restricted in the sense that the individual cannot sell the shares or exercise the options for two to four years after their last day in office. We refer to this as the Restricted Equity proposal. Many current compensation contracts require the forfeiture of restricted shares when an executive leaves the firm. Quite to the contrary, we are not suggesting that restricted shares (under our Restricted Equity proposal) be forfeited when the executive departs. In fact, we are advocating that restricted shares not be forfeited when the executive leaves the firm, but should be retained and the value received several years thereafter.

If the CEO in the stylized examples in section II had been offered incentive compensation contracts consistent with the Restricted Equity proposal, then she would have had more high-powered incentives not to invest in the high-risk, negative NPV trading strategy. Namely, the CEO's equity holdings would now consist only of restricted stock and restricted stock options. Not only would the CEO be required to hold these shares and options for the duration of her employment in the bank, but for two to four years subsequent to her retirement or resignation. If the trading strategy resulted in a positive cash flow in a certain year prior to their retirement or resignation, the bank's share price would go up, the CEO's net worth would go up on paper, but the CEO would not be able to liquidate her stockholdings. The CEO would note 2, at 145 ("our proposal applies to all executives and any individual whose decisions may substantially impact a firm (such as proprietary traders or structured product sales personnel...").

27. See supra note 2. We use the term "bank" as shorthand to refer both to banks and bank holding companies, which are more often the publicly-traded entity. 
have to make an assessment of the likelihood of the large negative cash flow outcome during the years she continued to be employed at the bank, plus two to four additional years. After making such an assessment, a CEO would presumably be less likely to authorize or encourage the high-risk but negative net present value trading strategy in the first place. The long-term feature of the Restricted Equity proposal's compensation package would operate similarly in the behaviorally optimistic, as well as the inadequate internal information structure, scenario: it could curb optimistic estimates of a project's NPV by using high-powered financial incentives to prod the executive to attend to, and hence estimate more assiduously, all of a project's cash flows, rather than solely those in the near term, as well as incentivize the executive to improve internal information flows. If a bank does not engage in the negative NPV investment project or trading strategy, then this would, of course, also serve the interests of the long-term shareholders.

The Restricted Equity proposal is consistent with several recent theoretical papers which suggest that a significant component of incentive compensation should consist of stock and stock options with long vesting periods. ${ }^{28}$ We note that we have suggested that the time frame extend two to four years after retirement, but we would leave the specific horizon to the board compensation committee, to whom the proposal is addressed. ${ }^{29}$ The rationale for this extended time frame is to maintain incentives for an executive in an "end-game" situation, i.e., an individual making decisions when he or she is reaching retirement. At the shorter end of our proposal, management's discretionary authority to manage earnings under current U.S. accounting conventions usually unravels within a one-to-two year period, although the actual period depends on the industry and the type of earnings management. ${ }^{30}$

28

E.g., Alex Edmans et al. Dynamic CEO Compensation, 67 J. FN. 1603 (2012);

Lin Peng \& Ailsa Röell, Managerial Incentives and Stock Price Manipulation (Apr. 20, 2013). (unpublished manuscript), http://ssrn.com/abstract=1321903; see also Patrick Bolton et al., Executive Compensation and Short-Termist Behavior in Speculative Markets, 73 REV. ECON. STUD. 577, 580 (2006) (" $[\mathrm{I}] \mathrm{f}$ the goal is to ensure the maximization of long-run fundamental value, then one may want to... lengthen stock-option vesting periods... and more generally take steps ensuring that controlling shareholders (or the board of directors) have a longer-term outlook."). While calling for longer horizons than pre-crisis plans, the optimal compensation package derived in the Edmans et al. and Peng \& Röell models is far more intricate than our proposal. However, as discussed at pages 121-22 infra, we believe that simplicity is a key feature of an effective compensation plan, even though it may come at the expense of simplifying what these models suggest would be a more optimal approach. The Restricted Equity proposal is also consistent with the model of Jokivuolle and Keppo in which shorter term bonus compensation structures increase risk-taking. Jokivuolle and Keppo, supra note 18.

29. See infra p. 122. We would also leave to the board whether the number of shares or options to be received under the plan should depend on a performance target, although we are wary of the efficacy of performance targets because managers focused on meeting a target may make decisions that negatively impact long-term value, such as decreasing margins to attain a sales target. While such an effect would be mitigated by the long-term horizon of restricted stock, if the number of performance-based shares is set too high, the immediate goal of receiving shares might offset attention to the long-term value effect of a decision.

30. For CFO beliefs about earnings management see, Ilia D. Dichev et al, Earnings Quality: Evidence from the Field (Oct. 30, 2013) (unpublished manuscript), http://ssm,com/abstr act $=2347428$. 
At the longer end, we think four years is a reasonable period in which at least the intermediate-term results of executives' decisions will be realized.

There is a finance literature suggesting that the appropriate vesting period for incentive compensation matches the life of the investments to be undertaken," with longer contract periods "particularly valuable to firms with . . . considerable information asymmetry regarding the long-term effects of current managerial actions." 32 Financial institutions are just such firms: the quality of their assets is opaque to outside investors and much bank lending is of quite long duration, even when securitized (due to banks' retention of the securities, provision of guarantees to investors purchasing such securities and their taking back onto their balance sheets securitized mortgages whose value had declined), as evidenced in the financial crisis. ${ }^{33}$ This makes the postretirement duration of the Restricted Equity proposal consistent, in our judgment, with that literature. ${ }^{34}$

How long would the Restricted Equity vesting period last in practice, on average, for a specific individual? Studies report a range for the median tenure of bank CEOs between five and eight years. ${ }^{33}$ Hence, on average, a CEO could expect to wait eight and one-half to ten and one-half years before being allowed to sell shares or exercise options. In the non-public corporation setting, it is

31. Several articles posit that compensation contract terms should match investment horizons and then find positive correlations between the length of firms' compensation plans and their having long-term investment projects. E.g., Stacey R. Kole, The Complexity of Compensation Contracts, 43 J. FIN. ECON. 79, 94, 97 (1997), (finding that firms with more intensive R\&D and innovative activity more likely to use restricted stock and stock option plans, consistent with long-term contracting being used by firms with long-term projects, and many of those firms required the restricted shares to be held until retirement); Brian D. Cadman et al., Stock Option Grant Vesting Terms: Economic and Financial Reporting Determinants, 18 REV. ACCNT. STUD. 1159 (2013) (finding that option grant vesting schedules longer in growth firms, where lengthening the CEO's investment horizon is "more important").

32. Cadman et al, supra note 31, at 1161.

33. E.g., Viral V. Acharya et al,, Securitization without Risk Transfer, 107 J. FIN. ECON. 515 (2013) (stating that commercial banks using asset-backed commercial paper conduits insured the securitized assets, with losses from conduits remaining with the banks rather than the outside investors); Juliusz Jablecki and Mateusz Machaj, A Regulated Meltdown: The Basel Rules and Banks' Leverage, in WHAT CAUSED THE FINANCLAL CRISIS? 200, 213-14, 223-24 (Jeffrey Friedman ed., 2011) (similarly describing how banks retained securitized assets in structured investment vehicles and provided guarantees to investors in the vehicles or had to take the vehicles back onto their balance sheets during the crisis).

34. But the optimal vesting period should match the life of the investment under the following assumptions: (i) the life of the investment is observable and verifiable; and (ii) the board is only concerned about aligning the incentives of the CEO for that one investment project. In most situations involving CEOs of large banks (or CEOs of any large firm) these assumptions are unlikely to be valid. Moreover, a plan that sought to combine in some fashion the optimal vesting period for a large institution's numerous investment projects of varying durations would be neither simple nor transparent, which would be contrary to the simplicity and transparency criteria of our compensation reform proposal. See infra pp. 121-22.

35. Robert DeYoung, Emma Y. Peng \& Meng Yan, Executive Compensation and Business Policy Choices at U.S. Commercial Banks, 48 J. FN. \& QUANT. ANALYSIS 165, 178 (2013) (finding a median tenure of eight years from a sample of 145 CEOs of 114 large banks over 1995-2006); Bhagat \& Bolton, supra note 22 (finding that the median tenure of CEOs of large banks (TARP recipients) is five or seven years, depending on the time frame). 
quite common for top executives to wait for seven to ten years before receiving a substantial portion of their compensation for work performed earlier. For instance, the general partners of private equity partnerships typically receive their compensation in two parts, the more substantial of which, carried interest (usually, 20\% of the lifetime profits generated by the partnership) are realized towards the end of the life of the partnerships, usually seven to ten years. ${ }^{36}$ The widespread use of such a deferred compensation structure in a real world setting where principal-agent problems are thought to be better-managed suggests that our proposal could substantially improve bank managers' incentives, despite well-known differences between the private equity and public company operating environments. A further benefit of the proposal's vesting period is that because a CEO would be exposed to the impact of decisions made by his or her successor, the executive will focus more attentively on succession planning.

In advancing our proposal previously, we noted several important caveats that we reiterate here. First, if executives are required to hold restricted shares and options, then they would most likely be under-diversified. ${ }^{37}$ Second, requiring executives to hold restricted shares and options into retirement raises liquidity concerns. Third, the proposal could lead to early management departures, as executives seek to cash out their accrued restricted shares and options (as soon, of course, as they can, given the two to four year postdeparture waiting period).

The deliberate under-diversification brought about by being subject to a Restricted Equity plan - more of an individual's wealth will be tied to the firm, as she cannot liquidate accumulated incentive equity payments beyond annual earnings - would lower the risk-adjusted expected return for the executive. One means of bringing an executive's risk-adjusted expected return back up to the previous level would be to increase the expected return by granting additional restricted shares and options to the executive. We would therefore expect that the amount of equity awarded under the Restricted Equity proposal will be higher than that awarded under a short-term incentive plan.

Executives might be expected to seek to reduce the under-diversification effect by entering into swap contracts that transform their restricted positions into liquid investments. To ensure that the incentive effects of restricted stock and options are not undone by self-help efforts at diversification, executives participating in such compensation plans should be prohibited from engaging in

36. ANDREW METRICK \& AYAKO YASUDA, VENTURE CAPITAL AND THE FINANCE of INNOVATION 32-33 (2nd ed. 2011). See also Kate Litvak, Venture Capital Limited Partnership Agreements: Understanding Compensation Arrangements 1 (Univ. of Tex. Law \& Econ. Research Paper No. 29, 2004), http://papers.ssm.com/sol3/papers.cfm?abstract_id=555626 (arguing that venture capital partners' compensation contains three, rather than two, components, with the third being the value of interest-free loans partners receive from limited partners specified by distribution rules determining when partners receive their share of profits).

37. Brian J. Hall \& Kevin J. Murphy, Stock Options for Undiversified Executives, 33 J. ACCOUNTING AND ECON. 3 (2002). 
transactions, such as equity swaps, or borrowing arrangements, that hedge the firm-specific risk from their having to hold restricted stock and options (where not already restricted by law). ${ }^{38}$

Of course, derivative transactions based on other securities, such as a financial industry stock index, could be used to undo the executives' interest in the restricted shares, subjecting the executive to the lower level of basis risk (i.e., the risk that co-movements in the firm's stock and the security or securities underlying the hedge are not perfect). To address this possibility, approval of the compensation committee or board of directors should be required for other (non-firm-specific) derivative transactions, such as a put option on a broader basket of securities. In addition, to ensure that underdiversification does not result in managers taking on too low a level of risk compared to the risk preferences of shareholders (behavior that may be of particular concern as an aging executive nears retirement and may wish to protect the value of accrued shares), the incentive plan can be fine-tuned to provide a higher proportion in restricted options than restricted shares to increase the individual's incentive to take risk.

The concerns regarding lack of liquidity and early departure are also valid. To address these concerns, we recommended that managers be allowed to liquidate annually a modest fraction of their awarded incentive restricted shares and options of between $10-15 \% .^{39}$ The requirement that they must retain the great bulk of the shares several years until after retirement or departure will provide a sufficient incentive to advance shareholder long-term interests. We further proposed that the annual corporate tax deduction for non-incentivebased compensation for individuals whose incentive compensation consists solely of a Restricted Equity plan be raised to $\$ 2$ million. ${ }^{40}$ Permitting $10-15 \%$ of each year's incentive compensation to vest and be sold, along with potentially receiving a higher cash base, will mitigate liquidity and early departure concerns, particularly for lower-level managers whose bonuses would not be as large as, and whose employment horizons would be longer than, those of CEOs. But we are also skeptical that the Restricted Equity plan will induce an onslaught of early departures by younger executives seeking to lock-in stock gains: executives who develop a reputation for early departures from firms are likely to impact negatively their future career opportunities.

We are further sensitive to potential tax liabilities that the Restricted Equity proposal might generate for an executive. To the extent an individual

38. There are constraints on executives' ability to hedge stock and option positions under tax and securities laws. See, e.g., David M. Schizer, Executives and Hedging: The Fragile Legal Foundation of Incentive Compatibility, 100 COLUM. L. REV. 440, 445 (2000).

39. BHAGAT \& ROMANO, LONG-TERM, supra note 2, at 148 . The allowance of some short-term cash payouts is consistent with the form of the optimal compensation package derived in the papers cited in note 28 , supra.

40. BHAGAT \& ROMANO, LONG-TERM, supra note 2, at 368 . The Internal Revenue Code limits the deduction to $\$ 1,000,000$. 26 U.S.C. $\$ 162(\mathrm{~m})(1)$. 
incurs tax liability from receiving restricted shares and options that is greater than the amount permitted to be liquidated in the current year, then under our proposal that individual would be allowed to sell enough additional shares (and/or exercise enough additional options) to pay the additional taxes.

Figure 1 provides an empirical perspective on the recommendation concerning the appropriate percentage of annual liquidations. ${ }^{41}$ It shows the percentage of firm-years, over the interval 2000-08, in which bank CEOs sold more than $5 \%, 10 \%$ or $15 \%$ of their stock holdings at the beginning of the time period. TARP recipient CEOs sold more than $5 \%$ of beginning holdings in $41 \%$ of the firm-years, compared to $16 \%$ of firm-years for the CEOs of non-TARP recipients. They also sold more than $15 \%$ of beginning holdings in $17 \%$ of the firm-years, compared to $6 \%$ of firm-years for the non-TARP recipient firm CEOs.

Given those data, the more limited equity shares that we would permit to be annually liquidated may seem low compared to the amounts that bank executives have been able to realize in the past (i.e., pre-crisis years). However, that is not necessarily the case when a longer time frame is considered. The proposal only limits the annual cash payoffs the executives can realize. The NPV of all salary and stock compensation can be higher than they have received historically, as the amount of restricted stock is unlimited. Of course, the higher value would only be realized were they to invest in projects that lead to value creation that persists in the long-term. In addition, concern over the proposal's impact on liquidity needs or early departures, when contrasting it to the Bolton and Bhagat past sales data, can stand a bit of perspective. Consider as a reference point the fact that the adjusted gross income (AGI) of the top $0.1 \%$ in 2004 had a threshold of $\$ 1.4$ million, ${ }^{42}$ while in 2011 the AGI cutoff for the top $0.1 \%$ was $\$ 1.7$ million. ${ }^{43}$ Accordingly, permitting executives a cash salary of $\$ 2$ million, and the ability to liquidate $10-15 \%$ of annual incentive compensation, is far from financially punitive.

\footnotetext{
41. See Bhagat \& Bolton, supra note 22 at 58-60 (providing the data from which Figure 1 is derived).

42. Steven N. Kaplan \& Joshua Rauh, Wall Street and Main Street: What Contributes to the Rise in the Highest Incomes?, 23 REV. FIN. STUD. 1004, 1015 (2010).

43. Steven N. Kaplan \& Joshua Rauh, It's the Market: The Broad-Based Rise in the Return to Top Talent, 27 J. ECON. PERSP., Summer 2013 at 35, 37 . The proposal's restricted availability of compensation might well lead talented traders and bank executives to migrate to hedge funds, whose compensation is not subject to regulation, nor is our proposal addressed to such entities. While a talent drain is most certainly of concem in terms of the important role banks play in the economy, this would otherwise not create a fiscal problem of note, unless hedge funds were to expand dramatically beyond their current size and scope, such as becoming a critical part of the payment system. In the recent financial crisis, for example, a number of hedge funds failed, including some quite large ones, but it was thought that none needed to be, nor were any, bailed out. Moreover, hedge funds' compensation structure is thought to be better aligned with value maximization than that of bank employees' pre-crisis compensation because hedge fund managers earn a performance fee only on increases in a fund's net asset value above the highest net asset value the fund has achieved in the past. See, e.g., SEBASTIAN MALlaby, MORE MONEY THAN GOD: HedGe FundS AND THE MAKING OF A NEW Elite 12 (2010).
} 
The Restricted Equity proposal will, no doubt, encourage managers to seek a considerably higher proportion of fixed cash salaries to compensate for the restricted ability to realize the value of equity incentive awards. But we posit that the higher deductible cash base, along with the modest amount of realizable equity gains, should mitigate both such efforts by management and decrease the probability that the members of compensation committees will perceive a need to succumb to such efforts. Indeed, there is evidence that bank directors are not potted plants when it comes to executive compensation, as they adjust executives' incentive compensation in response to the level of prior risk-taking. ${ }^{44}$

A final caveat is that the variety of compensation practices across firms might suggest that standardized pay packages, such as we are proposing, may be inefficient, because, for example, compensation may substitute or complement other governance mechanisms, which vary across firms. ${ }^{45}$ This is indeed a matter of concern. But the need for greater variety or customization in structuring incentive compensation is more pronounced across industries, where differences in assets and risk call for different governance, and correspondingly different incentive structures, than within an industry, and our proposal is focused on the banking sector. ${ }^{46}$ The Restricted Equity proposal is addressed to the banking sector because of the externality to the public fisc and the real economy when banks take on excessive risk, in contrast to other firms.

Of course, there are sharp, self-evident differences within the sector, e.g. between large complex banking organizations and small community banks. But excessive risk-taking can be a problem across the spectrum of financial institutions: although the global financial crisis was concentrated in the largest financial institutions, the cost to the fisc was quite large when many small banks failed during the S\&L crisis of the late 1980s and early 1990s. We therefore think the proposal is suitable for all financial institutions. And it does permit some tailoring at the edges: the amount and timing for liquidating annual incentive awards (within the 10-15\% suggested range), the number of years post-retirement before the employee can liquidate the balance, and the mix of restricted equity and options, for example. ${ }^{47}$

44.

DeYoung et al., supra note 35. The feedback loop was not present at a small subset of the very largest institutions (those with strong growth opportunities accompanied by very aggressive risk-taking).

45. See, e.g., David Walker, The Challenge of Improving the Long-Term Focus of Executive Pay, 51 Boston COLL. L. REV. 435, 447 (2010) (critiquing standardized compensation proposals due to concem over the heterogeneity of underlying incentive structures).

46. See Stuart L. Gillan et al., Tradeoffs in Corporate Governance: Evidence from Board Structures and Charter Provisions (April 2007) (unpublished manuscript), http://www.law.yale.edu/documents/pdf/cbl/starks_paper.pdf (indicating that governance mechanisms vary with firm characteristics that are related to assets and investment strategies).

47. To the extent that a board sought to motivate managers to undertake a specified short-term project, this could be accommodated in the Restricted Equity proposal by the performance targets used to determine the number of restricted shares or options the employee receives; although the individual would not be able immediately to realize the gain from such a project, she would be rewarded 
Most important, our proposal has the advantage of relative simplicity, compared to the complicated variety in existing packages with multiple incentive components. A simple incentive compensation structure is desirable for at least two reasons. First, the financial sector is particularly fast-moving, rendering it difficult to predict what risks may emerge as products and markets develop, and how individuals respond to regulatory and contractual incentives can alter risk in unanticipated ways that can evolve nonlinearly. ${ }^{48}$ Moreover, in today's context of large and interconnected financial institutions and complex financial instruments, banks must grapple with unknown and unknowable, and not simply known, risks. ${ }^{49}$ As a consequence, the more complicated and opaque an incentive package, the more difficult it will be to determine how individuals will respond, and what risks will or will not be incurred. The relative simplicity of the Restricted Equity proposal minimizes such difficulties, by collapsing the incentives to one: long-term stock value. Second, as shareholders are now required to vote on CEO compensation packages, a simple incentive structure is easier for them to understand and evaluate, reducing the need to rely on thirdparty vendors of proxy voting advice, the value of which service has been the subject of considerable controversy. ${ }^{50}$

Given the amount of government regulation already directed at banks' incentive compensation plans, which, as discussed in the next section, may well have perverse effects, we are directing our proposal at bank compensation

for achieving the short-term goal by the restricted unit allotment. Of course, our proposal seeks to address problems arising from a bank's compensation system's rewarding a project's short term return, and given the nature of bank assets, which are often long-lived investments, we would expect boards to need to have recourse to such measures infrequently. Similarly, the proposal could accommodate concern that division executives' and lower level employees' limited responsibilities and efforts are uncorrelated with stock performance by allocating restricted shares or options in relation to their units' accounting performance compared to specified targets or the accounting performance of competitors or the rest of the company. But we prefer stock performance measures, given the easier manipulability of accounting data. Moreover, the compensation literature contends that the appropriate performance measure-stock or accounting performance-relates to the relative reliability of the measure, e.g., Kole, supra note 31 , at 82 , and the opacity of banks' assets and off-balance sheet transactions suggests that stock prices would be more reliable than accounting measures in this context.

48. See Erwann Michel-Kerjan, Report No. 3: Financial Protection of Critical Infrastructure, INSTITUT VEOLIA ENVIRONNEMENT, http://www.institut.veolia.org/en/our-activities /archives/other-studies-published/report-n3-financial-protection.html (last visited Aug. 5, 2014) (examining the impact on financial markets of dynamic uncertainty arising from terrorism). The concept of dynamic uncertainty was developed in the literature on terrorism to differentiate terrorist risk from natural disasters; the materialization of risk in both instances is highly uncertain, but terrorists adapt their behavior in response to targets' protective actions, and thus affect risk over time. $I d$.

49. FRANCIS X. DiEBOLD et al., Introduction to THE KNOWN, THE UNKNOWN AND THE UNKNowable IN FinanCial RisK MaNAGEMENT 3 (Francis X. Diebold et al., eds. 2010).

50. Dodd-Frank Wall Street Reform and Consumer Protection Act of 2010, Pub. L. No. 111-203, 124 Stat. 1376, § 951 (2010) (hereinafter "Dodd-Frank") (extending to all U.S. firms a requirement Congress had previously imposed only on banks receiving TARP funds, that shareholders vote, in an advisory capacity, on CEO compensation). Some countries, such as the United Kingdom and Australia, already had say-on-pay requirements in place, while others, such as Germany, have adopted them since Dodd-Frank's passage. For an overview of the debate over the value added by proxy advisory services see, Paul Rose, On the Role and Regulation of Proxy Advisors, 109 MiCH. L. REv. FIRST IMPRESSIONS 62 (2011). 
committees, who, we urge, should voluntarily adopt a Restricted Equity plan as the preferred mechanism for aligning management's incentives so as to mitigate the taking of excessive risk. ${ }^{51}$ But we are of the view that it would be equally desirable for regulators to replace their existing compensation regulation with the Restricted Equity proposal.

We further are of the view that compensation committees should consider adopting the Restricted Equity proposal for directors' incentive compensation as well. Director compensation typically consists of a cash component (called the retainer), smaller cash amounts paid for attendance at board and committee meetings, and incentive compensation in the form of stock and stock option grants which vest over a period of time of a few years. While the theoretical and empirical literature on executive compensation is extensive, the literature on director compensation is relatively modest. We think that it is plausible to assume that incentives operate similarly in both employment positions. If, for example, directors can liquidate their vested stock and options, and a director feels the need to liquidate the position in the near future, then the director may focus on short-term performance that may be to the detriment of long-term shareholder value and the public fisc. It would therefore be prudent for bank director incentive compensation to be structured along the lines of the Restricted Equity proposal advanced for bank executives.

\section{B. Comparison to Regulatory Initiatives}

Regulatory initiatives regarding bankers' incentive compensation have emphasized the use of equity (as opposed to cash) bonuses, deferral, and clawbacks, to achieve compensation that does not encourage untoward risktaking. These are features of worldwide regulation because the approach reducing incentives for excessive risk-taking - was incorporated into the Basel Committee's supervisory principles at the direction of the G-20, and all nations in which globally important banks are located (as they are all members of the Basel committee), as well as many others, have enacted compliant regulation. ${ }^{52}$ The G-20 incentive compensation principles did not mandate any particular design or structure, but by requiring that incentive compensation be adjusted for risk, be symmetric with risk outcomes and be sensitive to the time horizon

51. If only some banks adopt the Restricted Equity proposal, that could lead to a selection effect whereby only risk-takers, or risk-avoiders, agree to work for those firms, compared to firms providing incentive compensation vesting over a shorter horizon, and those individuals opt for management policies that take on either too much, or too little, risk. However, this is not an insoluble issue. As previously noted, there are data indicating that boards adjust bank managers' incentive compensation in conjunction with changes in a bank's risk. See supra note 44. Further, bank regulators could exercise supervisory discretion to provide more favorable regulatory treatment to banks that have adopted the Restricted Equity proposal, by, for example, requiring banks to hold higher capital if they have not adopted that approach.

52. See FIN. STABILITY FORUM, supra note 1 , at 3. 
of risks, they were universally interpreted to require deferred equity compensation and clawbacks.

The G-20 incentive compensation principles were subsequently clarified and operationalized into implementation standards. ${ }^{53}$ The standards suggest that a "substantial portion of incentive compensation be variable, of which "a substantial proportion, such as more than $50 \%$ " should be equity-based, and of which "a substantial proportion. . . such as 40 to $60 \%$ " should be deferred for at least three years. ${ }^{54}$ Deferred equity compensation is, of course, at the heart of our proposal. But as this guidance makes clear, regulators have not gone so far as to require banks to adopt all equity based incentive compensation or longterm vesting periods that extend beyond retirement or resignation, as we recommend. Hence, in our judgment, bank compensation committees should not settle for mere compliance with the suggested standards, as they fall well short of adequately guarding against excessive risk-taking, nor should banking regulators shrink from further scrutinizing bank activities where incentive compensation packages merely meet the implementation standards.

The implementation standards address the symmetric risk principle by requiring that a substantial proportion of the variable equity compensation be subject to a share retention policy, with the unvested component of that deferred compensation to be subject to clawback upon "negative contributions" (i.e., poor realized performance) of the firm and business line. ${ }^{55}$ Congress codified clawbacks for all firms in the Sarbanes Oxley Act and the 2009 stimulus package, with further elaboration in Dodd-Frank, laying out as a specific trigger an accounting restatement. ${ }^{56}$ Dodd-Frank, for instance, mandates SEC rulemaking to require issuers with accounting restatements to recover from any executive officer the amount of incentive compensation, received in a three-year window prior to the restatement, which was in excess of what the individual would have received had the accounting statements been correct.

Clawback provisions such as those in Dodd-Frank are not, in our judgment, as effective an incentive mechanism as the Restricted Equity proposal. They are inherently difficult to compute (e.g., it is unclear how to

53. Id. The motivation for greater specification of the agreed-upon compensation principles was not solely to enhance the stability of the global financial system, but also to establish a "level playing field" across international banks' compensation practices. By limiting discretion regarding the principles' content, the expectation was that supervisory demands would be more uniform and international banks' compensation practices would more readily converge. Id. at 1 .

54. FIN. STABILITY BOARD, FSB PRINCIPLES FOR SOUND COMPENSATION PRACTICES: IMPLEMENTATION STANDARDS 3 (2009), http://www.financialstabilityboard.org/public ations/r_090925c.pdf.

55. Id. The principles, by contrast, simply stated that bonuses should diminish or disappear upon poor performance, without specifying amounts subject to specific clawback. FIN. STABILITY FORUM, supra note 1, at 3.

56. American Recovery and Reinvestment Act of 2009, Pub. L. No. 11-5, 7001,123 Stat. 115 (2009) (hereinafter "Stimulus Bill"); Sarbanes-Oxley Act of 2002, Pub. L. No. 107-204, §304, 15 U.S.C. $\$ 7243$ (2006); Dodd-Frank, supra note 50, §954. 
calculate the Dodd-Frank clawback measure when the award is not based on an accounting target), and entail litigation costs of uncertain dimension at present. ${ }^{57}$ Further, specific triggers for clawbacks are blunt instruments: excessive risk-taking causing firm losses need not produce a restatement (the decline in value of large financial institutions during the financial crisis was not accompanied by, or in response to, accounting restatements), nor might a threeyear horizon be enough time for a flawed investment or trading strategy to be revealed. ${ }^{58}$

By contrast, the Restricted Equity proposal has an inherent "clawback" feature that renders unnecessary intricate mechanisms requiring repayments of bonuses on income from transactions whose value proved illusory. Because executives are compensated in equity that is not received until years after it is earned - two to four years after they leave the firm-they cannot capture shortlived income from transactions whose value is not long-lasting. The compensation will be dissipated as the value of the firm's shares decline upon the realization of the transaction's losses. In other words, executives will receive less in value than the originally granted bonus compensation if the stock price drops thereafter. This automatic "clawback" is, accordingly, simpler to administer than the specified regulatory clawbacks, avoiding definitional, and consequently litigation, pitfalls.

57

See, e.g., Mary Hughes, Clawbacks Gain Favor, Raise Issues In Absence of Guidance, Speakers Say, 11 Corporate Accountability Report (BNA) 685 (2013). For instance, companies adopting clawback policies to comply with Dodd-Frank face the prospect of uncertain litigation costs because under most states' law, wages "once earned" cannot be clawed back. Therefore, companies will not be able to exercise "self-help" and achieve a clawback by not paying part or all of a current salary or bonus, but will have to sue an individual who does not voluntarily repay the amount in question for the funds. Id. There is also the prospect of costly litigation in the SEC's enforcement of the Sarbanes Oxley clawback provision. A few non-culpable executives, rather than settle, have challenged being subjected to a clawback without individual wrongdoing or knowledge. Although two district courts have rejected executives' motions to dismiss on that ground, SEC v. Baker, No. A-12-CA-285-SS (W.D. Tex., Nov. 13, 2012); SEC v. Jenkins, No. 2:09-CV-1510-GMS (D. Ariz. June 9, 2010), the issue is still unsettled. That is because one of the courts also found that the statute could raise constitutional issues of "severe and unjustified" deprivation but that such issues could not be decided on a motion to dismiss, SEC v. Jenkins, supra, at 9. Finally, there are also tax complications with clawbacks: under the "claim of right" doctrine, an individual has to pay tax on compensation received in a given year, even if he may "later be required to repay it." None of these additional complications would arise under the Restricted Equity proposal, while the executive would also not be able to reap inapposite gains from incentive compensation.

58. Bernard Hirsch et al. advance a further objection to clawbacks, that they may have the unintended consequence of increasing risk-taking. They hypothesize that clawbacks will have a differential impact on decision-making depending on a firm's financial position, and that where the investment outcome only affects the size of a loss, the manager with a clawback will select the riskiest project, as with a higher variance, it offers a possibility of reducing the extent of the loss, and hence the amount of compensation clawed back. Bernard Hirsch, Bernhard E. Reichert \& Matthias Sohn, Does Holding Managers Accountable by Extending the Scope of Clawback Provisions in Incentive Contracts Backfire and Lead to More Risk Taking by Distorting Information Processing? (May 23, 2014) (unpublished manuscript), http://ssm.com/abstract=2312487. They provide findings from a laboratory experiment that support the hypothesis, as in the setting of a loss position, individuals with clawback compensation contracts opted more frequently for the riskier of two projects, than those without clawbacks. Id. at $2-4$. 
The EU has gone further than the G-20 and Basel-endorsed approach and capped bankers' incentive pay to no more than the individual's fixed salary. ${ }^{59}$ In our judgment, a proposal could not be more wrong-headed than that legislation if the objective is to incentivize bank executives to maximize firm value and reduce excessive risk. ${ }^{60}$ There is a well-developed and widely accepted economics literature on how to achieve consonance between managers' actions and shareholders' interest through the use of incentive stock and option compensation. ${ }^{61}$ The less the executive receives in incentive compensation, the less he or she will be motivated to act so as to maximize share value. The core problem of excessive risk-taking is not one of compensation levels, but of compensation structure. Moreover, the likely result of any restriction capping one component of compensation is to increase another component. As the original package proportions would have reflected a market equilibrium package maximizing employee utility, the new package will be inefficient, i.e., the mandated change will require a compensating adjustment that costs the firm more than before. ${ }^{62}$ In short, such a restriction will make pay even less sensitive to performance than it was before the crisis, which is the precise opposite of what is desirable in an incentive compensation plan.

59. See supra note 1. In 2009 , for a brief period some U.S. banks were subject to a similar restriction: Congress limited the incentive pay of executives of firms receiving TARP funds to $1 / 3$ of their annual compensation, Stimulus bill, American Recovery and Reinvestment Act, supra note $56, \S 7001$. But all of the TARP-recipient banks rapidly paid off their TARP obligations and exited the program. BHAGAT \& ROMANO, LONG-TERM, supra note 2, at 140 . No doubt, avoiding the restrictions on compensation provided a powerful incentive to do so.

60. It is, of course, quite possible that the motivation of members of the European Parliament adopting the cap was to punish bank employees and express moral outrage at their outsized pay packages and not to affect banks' risk-taking incentives. In our judgment, if that was the motivation, then the solution is misplaced, as it undermines the fashioning of an effective compensation system for banks, and concerns over income inequality are best addressed by national tax and transfer systems.

61. E.g., Bengt Holmstrom, Moral Hazard and Observability, 10 BELL J. ECON. 74 (1979); Bengt Holmstrom, Managerial Incentive Problems-A Dynamic Perspective, 66 REV. ECON. STUD. 169 (1999).

62. Evidence can be adduced of the perverse effects of government efforts to restrict the amount of executive compensation. For example, after U.S. corporate tax-deductible pay was limited to $\$ 1$ million for fixed compensation but not for performance-based pay, firms altered the mix of compensation to reduce cash salaries and increase incentive compensation. See Tod Perry \& Mark Zenner, Pay for Performance? Government Regulation and the Structure of Compensation Contracts 17 (June 2000) (unpublished manuscript), http://papers.ssrn.com/sol3/papers.cfm?abstract_id=60956. Some commentators attribute the mushrooming of equity incentive compensation and hence executive pay in the 1990 s, along with the excessive risk-taking of the 2000s, to that reform. E.g., Bruce Bartlett, Not so Suite: Clinton Tax Law is the Problem, Not Greedy Execs, NAT'L REV. ONLINE (Sept. 25, 2002, 9:00 AM), http://www.nationalreview.com/nrof_barlett/bartlett092502.asp. A similar reaction appears to be occurring in Europe: $65 \%$ of U.K. financial services companies increased the base salary of their employees by over $20 \%$ in anticipation of the incoming cap. See, e.g., Daniel Schäfer, Salaries Lifted to Beat Bonus Cap, FIN. TIMES, Aug. 20, 2013, 5:32 PM, http://www.ft.com/cms/s/0/0ff854c2-08e4-1 le3ad07-00144feabdc0.html. For a similar criticism of the EU initiative see Kevin J. Murphy, Regulation Banking Bonuses in the European Union: A Case Study in Unintended Consequences, 19 EUR. FiN. MGT. J. 631 (2013). As earlier noted, we recognize that the Restricted Equity proposal may have this type of effect, and suggest means by which it can be mitigated: increasing award amounts to compensate for increased under-diversification and permitting modest liquidation of annual awards. 


\section{Comparison to Debt-Based Compensation Proposals}

As earlier noted, a number of recent reform proposals have advocated compensating bank managers with a share of the bank's debt securities, rather than (or in addition to) equity-based incentive pay. ${ }^{63}$ Although specifics of the proposed debt or debt-like compensation differ, the rationale is the same: to address the moral hazard, or agency problem of debt, using an idea first advanced by Michael Jensen and William Meckling in a classic article published over thirty years ago, to compensate managers with debt as well as stock to mitigate equity's incentive, in a levered firm, to take on increasingly risky projects because it obtains the entire upside but does not have to pay creditors in full on the downside, given limited liability. ${ }^{64}$ Deposit insurance exacerbates the moral hazard problem because the government stands behind the equity holders, and it reduces creditors' incentives to monitor managers' risk-taking or otherwise seek contractual protections against risk-taking. Of course, this moral hazard problem resulting in a threat to the fisc is universally recognized: banks are for this very reason subject to extensive supervision, regulation and examination.

All of the debt-based proposals are, in our judgment, inferior to our Restricted Equity proposal, particularly given the earlier noted desirable property that compensation plans be simple to understand, implement and monitor, as well as be aligned with long-term firm value. First, reform proposals advocating a package of equity and debt or debt-like securities are far more complex and opaque than the Restricted Equity proposal. For example, most senior securities of financial institutions are either not publicly traded or

63. See Lucian A. Bebchuk \& Holger Spamann, Regulating Bankers ' Pay, 98 GEO. L.J. 247 (2010) (recommending compensation package of a proportionate mix of financial institutions' senior securities-debt and preferred stock-and equity); PATRICK BOLTON, HAMID MEHRAN \& JOEL SHAPIRO, FED. RESERVE BANK OF N.Y., EXECUTIVE COMPENSATION AND RISK-TAKING, STAFF REPORT NO. 456 (2010) (recommending tying compensation to changes in the spread on credit default swaps, which are contracts written on debt securities that insure the holder against the debt's default); Jeffrey N. Gordon, Executive Compensation and Corporate Governance in Financial Firms: The Case for Convertible Equity-Based Pay, 2012 COLUM. BUS. L. REV. 834 (advocating conversion of financial institutions' senior management's equity-based compensation into subordinated debt at a discount to the equity value, when a firm experiences financial difficulty); Wulf A. Kaal, Contingent Capital in Executive Compensation, 69 WASH. \& LEE L. REV. 1821 (2012) (recommending use of contingent convertible bonds with an early conversion trigger); Frederick Tung, Pay for Banker Performance: Structuring Executive Compensation for Risk Regulation, 105 Nw. U. L. REV. 1205 (2011) (recommending compensation in the form of subordinated debt of the bank subsidiary). A detailed discussion of what are, in our judgment, feasibility and transparency problems with the BebchukSpamann proposal that make it inferior to our restricted stock proposal, is provided in Bhagat \& Romano, Simplicity, supra note 2. We discuss here the overall shortcomings of debt-focused compensation proposals.

64. Michael C. Jensen \& William H. Meckling, Theory of the Firm: Managerial Behavior, Agency Costs and Ownership Structure, 3 J. FIN. ECON. 305, 352 (1976). Jeffery Gordon further advocates the use of contingent debt compensation on the rationale that management with a large block of equity will not raise needed additional equity capital at a time of financial distress in order to avoid dilution of their ownership. Gordon, supra note 63. But see infra Section IV.B for our discussion of this issue and its relation to our proposal. 
trade very infrequently; the absence of market prices renders it difficult to value debt-based compensation packages. In addition, given that firms' capital structures are dynamic, changing over time, executives' portfolios will require frequent rebalancing to maintain proportionate holdings, upon issuance of new securities, or receipt of incentive compensation, to ensure maintenance of the proportions, which will require a complicated, and therefore costly, administration.

Proposals that advocate pegging compensation to a specific debt security, such as credit default swaps, rather than a proportionate package of the capital structure, while seemingly avoiding complexity, do not satisfactorily avoid the problem, as those securities are typically not publicly traded. ${ }^{65}$ They are also issued by only the largest financial institutions, and therefore are not suitable for executive compensation in medium- and small-sized financial institutions. Finally, determining the appropriate formula with which to relate changes in default spreads to executive compensation bonuses or clawbacks would undoubtedly be challenging, for the calculation of swap prices is complex, as values do not change linearly with changes in other economic variables. ${ }^{66}$

Second, government bail-outs of banks, particularly in the 2008 global financial crisis, have by and large focused on bailing out creditors, not shareholders. Given that experience, providing a portion of bank executives' compensation in debt would not lead the executives to take a socially optimal level of lower risk, as they could quite plausibly conclude that they need not expect to lose the value of debt securities on the downside while they will still expect to obtain the upside on the equity portion. If the executives' debt is

65. Besides the lack of transparency from the absence of market pricing, because credit default swap spreads are computed using accounting figures which are partially under managers' control, they may also be subject to manipulation, as managers will have increased incentives to misrepresent figures used in swap pricing when it immediately will impact their compensation. Although credit default swaps have historically traded in private over-the-counter markets, Dodd-Frank requires regulators to implement rules to establish the use of centralized clearing exchanges to trade these products, which could increase the transparency of prices, but will not eliminate the need for accounting data to calculate the spreads, as the underlying debt is infrequently traded. The convertible security proposed by Gordon, supra note 63, has further valuation difficulties: because management's stock differs significantly from that of outside stockholders (i.e., their shares will become debt securities, which are senior to the outstanding shares of the stockholders, when the firm experiences financial difficulty), their stock will not be equivalent in value, nor will its value move in tandem with the value of, the outstanding common stock. Moreover, determining the value of management's equity will be complicated because it depends on the likelihood of conversion, and the rate that will be applicable (which under the proposal requires a further probability calculation of the value of the common stock at an unknown point in time that is prior to the moment at which conversion occurs). Finally, the possible conversion into debt at a discount reduces the value of stock compensation to an executive and consequently, the executive will require a higher amount of equity to offset the lower valuation (i.e., the increased risk).

66. In discussing the formal model underlying their proposal to tie bank executives' compensation to credit default swap spreads, the optimal compensation contract consists of debt and equity in a ratio equal to the "rate of return promised to bondholders at the optimal risk level," which, as Bolton and colleagues note, "may be difficult to calculate." Bolton et al., supra note 63, at 13. In our judgment, this statement is gentle. As all of the proposal's incentives operate through the debt portion of compensation (the risk of default), from an incentive perspective it is closer to Tung's all-debt proposal than the proportional capital structure package proposed by Bebchuk and Spamann. 
written so as to not be able to participate in a government bailout, then those securities would be of lesser value than those sold to investors, whose prices and terms incorporate the reasonable expectation of a bailout should the institution fail, rendering market prices, such as exist for the debt, inapposite for valuing the executive's compensation. ${ }^{67}$ Yet that is the linchpin of such proposals, in which price signals of the riskiness of the debt, such as a bank's credit-default swap spread, or proportionate values of debt and equity securities, determine the executive's compensation.

Third, although in theory a manager holding a mix of debt and equity securities might not take on inappropriate risk, it might well be otherwise. The gain on an equity position from following a high risk strategy might well exceed the loss on the position attributable to senior securities in the executive's portfolio. Moreover, if the value of the equity position is quite low compared to the senior securities in a compensation package, a manager would still have an incentive to take on risky projects, given the option value of the position each year. ${ }^{68}$ Furthermore, the incentive to undertake riskier projects would be greater than the incentive to take on such projects created by our Restricted Equity proposal because with restricted stock, the option value cannot be realized until years after the manager is no longer with the firm. Indeed, as we discussed earlier, incentive compensation paid in the form of restricted stock is more likely to decrease than increase managers' risk-taking, as it increases the under-diversification of executive portfolios, in addition to the long-term holding period for the stock.

The concern over moral hazard in relation to bank risk-taking induced by deposit insurance which motivates the proposals to use debt for bank executives' incentive compensation, is, of course, as we have noted, wellrecognized, and we do not wish to dismiss its seriousness; that is a reason why financial institutions are our specific focus. But we think it is daunting to determine, no less effectively implement, an optimal incentive compensation structure combining debt and equity. It would in fact be extraordinarily difficult to determine how the incentives would work, i.e., how managers would react,

67. It would also further separate the executives' incentives from that of the firm's security holders, and as such could result in negative enterprise value, given the research relating executives' fixed claims to firm value. See infra note 71 and accompanying text.

68. Stock in a levered firm, from a finance perspective, is equivalent to an option on the firm, in which the equity holder obtains the upside of future risky projects but can walk away from the firm, without repaying creditors, if the firm's downside value is less than its liabilities. Richard Lambert et al. model when stock option compensation results in managers taking less or more risk (which depends on how "in the money"-i.e., by how much the exercise price is below the stock pricethe options are). Richard A. Lambert, David F. Larcker \& Robert E. Verrecchia, Portfolio Considerations in Valuing Executive Compensation, 29 J. ACCT. RES. 129 (1991). The model indicates that managers are more likely to take on risk when the probability of the option finishing in the money is low, as in the scenario in the text, and thus of greatest concern to the fisc. With restricted stock, the longer horizon increases the probability that an option will finish in the money, which, in the Lambert et al., model, increases the manager's aversion to risk. 
to such compensation. ${ }^{69}$ Moreover, the problem becomes more acute if the manager's loyalty is divided across firm stakeholders, as would be the case in these complicated multi-security structured compensation packages. If we move out of the realm of decisions regarding a specific investment, such as selling a particular structured product, to higher level firm decision issues, the manager may not make decisions to maximize firm value, as the conflicts of interest across the classes of securities may make it difficult, if not impossible, to determine the appropriate course to follow, with the result that the manager instead maximizes her own utility. ${ }^{70}$

Finally, the empirical research on which some debt-based compensation advocates offer in support of their proposals - that firms whose executives receive higher deferred compensation and pension benefits, which are considered to be debt-like as they are unsecured future claims, are less risky when evaluated more closely, we believe, cuts against the position. ${ }^{71}$ That research also finds that as the level of deferred compensation and pension benefits rises, total enterprise value falls (i.e., increases in debt values are swamped by decreases in equity value). To avoid such an outcome, the compensation package must mirror exactly the firm's total security package, which, as we have already discussed, is practically impossible to implement. A rational incentive compensation plan should not, of course, create negative firm value. Thus, it would be extraordinarily important to get the amount of debt held compared to stock precisely correct, which requires perfectly paralleling the firm's total package of securities, a feat, as we have discussed, that will be close to impossible to accomplish.

There is a further problem with debt-based incentive compensation from a social welfare point of view: it is not desirable from society's' perspective to run banks in debtholders' rather than shareholders' interest because banks that seek to minimize risk-taking might be induced to restrict their lending, and lend only to the safest borrowers, a business strategy, which, as seen in the postcrisis economy-wide recession, is not conducive to economic growth. As elaborated in the next part, we think instead that the moral hazard or agency costs of debt problem is best addressed directly by regulation raising bank (critiquing debt-based bank executive incentive compensation proposals that emphasizes behavioral economic difficulties).

70. For a classic exposition of the well-known difficulty of collective choice and the reason for corporate law's restriction of managers' fiduciary duty to shareholders, see Henry Hansmann, Ownership of the Firm, 4 J. LAW, ECON. \& ORG. 267 (1988).

71. E.g., Bolton et al., supra note 63 , at 2 . The key article assessing the impact of deferred compensation on stock and bond value uses the change in SEC disclosure rules that first required firms to reveal such holdings, to evaluate the impact. Chenyang Wei \& David Yermack, Investor Reactions to CEOs' Inside Debt Incentives, 24 REV. FIN. STUD. 3813 (2011). Deferred compensation and pension benefits are referred to in the literature as "inside debt." For a further critique of relying on research on "inside debt" to advocate debt-based compensation, see Alces \& Galle, supra note 69 . 
capital requirements, or changes in the forms of debt issued, such as greater use of hybrid debt instruments which convert to equity in specified adverse states of the world. By revising the capital structure to make the probability of insolvency from a tail event less probable, the Restricted Equity proposal would operate in the range in which bank managers' incentives, aligned with long-term share value-maximization, will also be aligned with long-term firm value-maximization. Indeed, for most states of the world, banks operate in an area, far from insolvency, in which equity rather than debt-based compensation provides superior incentives for firm value-maximization.

\section{Capital Structure and Executive Compensation}

We advocate two approaches, not necessarily exclusive, to bank capital structure reform that, coupled with the Restricted Equity proposal, should incentivize bank executives not to take on projects of excessive risk: meaningful higher capital requirements and mandatory issuance of CoCos. While we do not have unique insights on the issues, we think the evidence is compelling that not only pre-crisis but also post-crisis regulatory capital requirements were and are too low. But concurrently, in all truth, the optimal level of capital is both unknown and in all likelihood unknowable. Consequently, we believe that the best means of ascertaining what amount of capital should be required is by creating a mechanism to facilitate regulatory diversity within the global financial regulatory regime through which nations can experiment with different approaches to enhancing capital requirements beyond Basel III's strictures. By such a mechanism, information will be generated concerning what works best under varying circumstances, improving the quality of decision-making and the resiliency of the global financial system.

\section{A. Raising and Simplifying Bank-Capital Requirements}

Large international banks' capital requirements have been globally harmonized, under the Basel accords, since 1988. Basel capital calculations take into account an asset's risk, that is, banks are required to hold more capital for riskier assets, such as corporate loans, than they are required to hold for what are considered safer assets, such as government debt. The initial accord has been revised several times, with each succeeding revision resulting in more complex calculations of risk, and layered on top of existing provisions. Under Basel I, regulators established standardized risk weights for broad categories of assets. Banks were then required to hold a minimum of $8 \%$ capital against those assets. ${ }^{72}$ The standardized approach was emended under Basel II for the largest

72. For example, if a bank made a loan to a business of $\$ 1$ million, given the $100 \%$ risk weight for such assets, the bank would need capital in the amount of $8 \% \times 100 \% \times \$ 1$ million $=$ $\$ 80,000$. By contrast, if it used the same $\$ 1$ million to buy a U.S. treasury bond, given the $0 \%$ risk weight for sovereign debt, it would not need to hold any capital against that asset, despite total asset 
banks to apply a methodology by which regulators enlist banks' own more sophisticated internal risk management models to determine their risk-based capital requirements ("Internal Ratings Based" or "IRB"). ${ }^{73}$

Following the global financial crisis, the accord was further amended, first (Basel 2.5) to increase the capital requirements for securitized and off-balancesheet assets at the core of the global crisis that had had preferential treatment, and then (Basel III) to add a further capital conservation buffer equal to $2.5 \%$ of risk-weighted assets to the existing $8 \%$ minimum capital requirement, along with a $3 \%$ leverage ratio and requirements to hold a specified amount of liquid assets. ${ }^{74}$ A leverage ratio calculates the amount of capital in proportion to total assets independent of risk. Although new to international regulation, U.S. banking regulators had long imposed a $4 \%$ leverage ratio on domestic banks in addition to the Basel risk-weighted minimum capital requirement. ${ }^{75}$

The post-crisis refinements to Basel II also expanded the assets against which capital must be held, increased the risk weights allocated to specific assets, and restricted the definition of bank capital, such that even without the additional capital buffer (which has a long phase-in period) and despite retaining the Basel II capital minimum, banks would have to hold more capital than previously if they were not to alter the composition of their portfolios in response. The final piece of Basel III is an agreement by the Basel Committee that the largest, globally systemically important banks ("G-SIBs") should be subject to enhanced capital requirements. G-SIBs will be classified into different "buckets" according to the institution's systemic importance, with the

value remaining unchanged. Bank regulatory capital is divided into two tiers, with Tier 1 consisting essentially of common stock, and Tier 2 including additional instruments, such as specified forms of subordinated debt. Under Basel I, half of the required capital amount (or 4\%) had to be met with Tier 1 capital. These are accounting capital ratios, that is, Tier 1 is computed according to the book value, not market value, of the bank's common stock.

73. IRB was intended to address regulatory arbitrage opportunities created by the arbitrary requirements of the standardized approach, such as, for instance, banks cherry-picking assets within a category to increase their yield, i.e., the riskiest assets, without incurring an increased capital charge because the standardized risk categories were insensitive to the risk of specific borrowers or assets within the class. E.g., DANIEL K. TARUllo, BANKING ON BASEL 80-82 (2008) (discussing regulatory arbitrage opportunities afforded by Basel I). For a discussion of the operation of capital requirements under both accords as well as a critique of IRB, see id.

74. Basel III requires that $6 \%$ of the total $8 \%$ capital requirement be Tier 1 capital, and of that, $4.5 \%$ must be equity. The minimum capital requirements are to be phased in by 2015 while the phase in of the conservation buffer and leverage ratio requirements will not be completed until 2019 and 2018, respectively. BASEL COMM. ON BANKING SUPERVISION, BANK FOR INT'L SETTLEMENTS, BASEL III: A GLOBAL REGULATORY FRAMEWORK FOR MORE RESILIENT BANKS AND BANKING SYSTEMS 69 (rev. June 2011), http://www.bis.org/publ/bcbs $189 . \mathrm{htm}$. The Basel III minimum capital and conservation buffer requirements are said to have been determined by the loss experience of large banks over the past decade and in the 2008 crisis, respectively. Daniel K. Tarullo, Member, Bd. of Governors of the Fed. Reserve Sys., Remarks at the Peter G. Peterson Institute for International Economics: Regulating Systemically Important Financial Firms 8 (June 3, 2011) (transcript available at http://www.federalreserve.gov/newsevents/speech/tarullo20110603a.htm).

75. Continuing with the $\$ 1$ million loan example in note 72 , supra, under the leverage ratio requirement, the bank must hold the same amount of capital against a $\$ 1$ million asset, whether it is a corporate loan or a treasury bond, of $4 \% \times \$ 1$ million $=\$ 40,000$ (or under Basel III, $3 \% \times$ $\$ 1$ million $=\$ 30,000$ ). 
surcharge of additional risk-weighted capital ranging from 1 to $2.5 \%$ (as no banks will be placed into the highest bucket calling for $3.5 \%$ ). ${ }^{76}$ As with the capital conservation buffer, if a G-SIB's capital falls below the required surcharge, it will be penalized by restrictions on payouts to shareholders and employees, along with development of a remediation plan to increase its capital, rather than be subjected to more stringent corrective action, as could occur on a breach of minimum capital requirements. ${ }^{77}$

Although the increase in capital requirements is a move in the right direction, to our minds the Basel III level is still too low for comfort for reducing incentives to take excessive risk. We come to this understanding by reference, as a benchmark, to the level of capital held by banks pre-crisis, and the level that markets required of banks before governments stepped in to insure depositors. Consider first pre-crisis capital levels: a comprehensive study of leverage across banks and countries indicates that at the start of the financial crisis, U.S. banks' average capital was approximately $10-12 \%$ (that is, around $90 \%$ of their capital structure consisted of debt securities). ${ }^{78}$ At a debt level of $90 \%$, a market shock adversely affecting asset value of slightly over $2 \%$ could push a firm below the minimum capital requirement, subjecting it to corrective regulatory action, and such firms' executives would therefore be operating in what is analogous to the insolvency zone for nonfinancial firms, in which managers' incentives and shareholders' interest align in taking high risk gambles on firm value due to limited liability.

Moreover, although from the perspective of capital regulation pre-crisis banks might have appeared to be well capitalized, as they were operating above the regulatory minimum threshold, the financial crisis demonstrated that

76. BASEL COMM. ON BANKING SUPERVISION, BANK FOR INT'L SETTLEMENTS, GLOBAL SYSTEMICALLY IMPORTANT BANKS: UPDATED ASSESSMENT METHODOLOGY AND THE HIGHER LOSS ABSORBENCY REQUIREMENT (2013), http://www.bis.org/publ/bcbs255.htm. The additional capital must be Tier 1 capital. The Basel Committee document states that national regulators may impose higher requirements on their G-SIBs, which is the implicit understanding for all Basel requirements, and no doubt was an acknowledgement that members of the committee were intending to do so. U.S. banking regulators, for instance, have proposed a leverage ratio of $5 \%$ for the largest bank holding companies and $6 \%$ for their bank subsidiaries. U.S. Treas. Dep't, Fed. Res. Sys., FDIC, Regulatory Capital Rules: Regulatory Capital, Enhanced Supplementary Leverage Ratio Standards for Certain Bank Holding Companies and their Subsidiary Insured Depository Institutions, __ Fed. Reg. _ (July 2013). They were directed by Congress to impose an additional leverage requirement on such institutions. See DoddFrank, supra note $50, \S 165$.

77. The G-SIB surcharge is subject to as long a phase-in as the capital buffer, by 2019. See BASEL COMM. ON BANKING SUPERVISION, supra note 76, at 15.

78. See Sebnem Kalemli-Ozcan, Bent Sorensen \& Sevcan Yesiltas, Leverage Across Firms, Banks, and Countries, 88 J. INT'L ECON. 284 (2012). Because they are derived from publicly disclosed information, these data are simple leverage ratios, not Basel risk-weighted ratios. They also do not include off-balance sheet assets (given the limitation of the data), but those assets were, for the most part, also not included in the Basel risk weight calculation. The average level of debt was considerably higher at the former investment banks and European banks (firms that were not subject to a leverage ratio). See Andrew G. Haldane, Exec. Dir., Fin. Stability, Bank of Eng., Banking on the State, Remarks at the Federal Reserve Bank of Chicago's Twelfth Annual International Banking Conference (Sept. 25, 2009) (transcript available at http://www.bis.org/review/r09111le.pdf) (connecting this discrepancy to leverage ratio requirements). 
assumption was mistaken. ${ }^{79}$ Yet Basel III will raise the amount of required equity only to $4.5 \%$ (the minimum Tier 1 equity capital requirement). Such a requirement would hardly appear to be sufficient to withstand a repeat of the recent near catastrophic collapse of short-term financing markets and the banking sector, in which the shock to asset values was as large as the amount of banks' capital (that is, some large banks' equity declined from $10 \%$ to near zero). ${ }^{80}$

In line with this intuitive assessment, a study estimating the probability of bank losses in financial crises estimates the probability of a shock of the magnitude of a $10 \%$ decline in banks' risk-weighted assets is approximately $2.5 \%$ (a shock that has occurred historically once every 40 years). ${ }^{81}$ If riskweighted assets equaled half of a bank's assets, ${ }^{82}$ and its remaining safe assets were unaffected, then with such a shock the current minimum capital ratio would be insufficient. Adding in the $2.5 \%$ capital conservation buffer, on the assumption that bank managers will not want to cut off dividends and bonuses, would render the bank capable of weathering such a storm. However, the assumption that the value of assets to which no risk-weights are attached will be unaffected when there is such an extreme market shock to risk-weighted assets would seem problematic, given recent experience. In the Eurozone sovereign debt crisis following in the wake of the global financial crisis that began with a market shock to subprime mortgage securities, the value of many sovereigns' debt, previously perceived as a safe asset, precipitously cratered.

Consider, second, historical capital levels. Prior to the introduction of deposit insurance, U.S. banks routinely held capital over $20 \%{ }^{83}$ This level would appear to have been market-driven, as it exceeded (indeed was unrelated to) the amount required by regulation at the time. For instance, some states

79. Basel advocates could, no doubt, contend that the pre-crisis ratios were misleading as in retrospect it is clear that both banks and regulators inadequately measured the risk of assets, such as securitized mortgages, and that Basel III has sorted that out. But while that may be so, there is no reason to believe that the methodology is now sufficiently accurate such that some other asset's future risk will not prove to be greater than the weight that has been currently assigned, creating another crisis. It is true that banks will tend to hold more capital than the minimum requirement in order to avoid being pushed below the minimum by a small shock and thereby be subjected to regulatory corrective action, but the regulatory objective should be to establish a sufficient minimum against tail risk, independent of whether banks might hold a cushion of capital above that minimum.

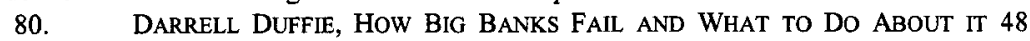
(2010). Citigroup illustrates the problem. Its Tier 1 capital ratio never fell below $7 \%$ during the financial crisis yet its stock market capitalization declined to approximately $1 \%$ of its total accounting assets. Id.

81. David Miles, Jing Yang \& Gilberto Marcheggiano, Optimal Bank Capital, 123

ECON. J. 1, 24 (2013).

82. Id. at 21 . This is approximately the percentage held by large U.K. banks in recent years. $I d$.

83. See e.g., Haldane, supra note 78 , at 14; Tarullo, supra note 73 , at 31 . There is striking suggestive evidence that the market priced the probability of the moral hazard problem caused by limited liability in relation to bank capital: In states where bank shareholders had liability for a proportion of a bank's debt beyond what they had invested (referred to as "double" liability), the average capital ratios were lower at $18.2 \%$ compared to $22.9 \%$ for banks in states where shareholders did not have such liability. Jonathan R. Macey \& Geoffrey P. Miller, Double Liability of Bank Shareholders: History and Implications, 27 WAKE FOREST L. REV. 31, 35, 59-60 (1992). 
during this period required banks to hold a capital to deposit ratio of $10 \%$, and national banks were subject to a similar requirement as of $1914 .{ }^{84}$ U.K. banks similarly had much higher capital, with leverage into the 1960s equal to half the rate of recent decades. ${ }^{85}$ The higher level of capital held in the pre-deposit insurance world suggests that is the level at which creditors expected bank management's risk-taking to be controlled. In our judgment, this is probative evidence that Basel requirements are too low, for it suggests that creditors are willing to invest in banks with today's lower level of equity because of the modern phenomenon of government bailouts, in which all creditors, not just insured depositors, are covered. ${ }^{86}$ We should note that a number of commentators have similarly advocated capital requirements significantly higher than $10 \%{ }^{87}$ And the Swiss banking regulators, who have had a reputation for probity, are evidently of that view, as they have required their largest banks to meet a capital requirement of $19 \%(10 \%$ of which must be equity). ${ }^{88}$

However, we quite candidly admit that beyond the general statement that current capital levels (including Basel's phased increase to roughly $10 \%$ ) would appear to be inadequate, we do not have a precise answer to the question what is the optimal capital requirement. We also think that is an answer no one can provide with confidence, and for any answer there will be considerable room for reasonable disagreement. ${ }^{89}$ One compelling explanation why it is

\footnotetext{
84. Tarullo, supra note 73 , at 29.

85. Miles et al., supra note 81 , at $3-4$; see also Haldane, supra note 78 , at 14 (explaining that capital ratios for U.K. banks were over $10 \%$ until around WW I).

86. It should also be noted that European banks, which have been more highly levered than U.S. banks, have issued large amounts of "covered" bonds, in which, creditors have claims upon specific collateral for repayment. E.g. INT'L MONETARY FUND, GLOBAL FINANCIAL STABILITY REPORT: TRANSITION CHALlENGES TO STABILITY 109 (2013), http://www.imf.org/external/ pubs/ft/gfst/2013/02/pdf/text.pdf; Simon Constable, In Translation: Covered Bonds, WALL ST. J., July 9, 2012. http:/online.wsj.com/news/articles/SB10001424052702303665904577450733636151 106.

87. Anat R. Admati et al,, Fallacies, Irrelevant Facts and Myths: Why Bank Equity is Not Expensive 58 (Stanford GSB Research Paper No. 2065, 2011) ("[E]quity capital ratios significantly higher than $10 \%$ of un-weighted assets should be seriously considered."); ANAT ADMATI \& MARTIN Hellwig, The Bankers' New Clothes 179-82, 189 (2013) (advocating capital leverage ratios of $20-30 \%$, allowing for time-varying regulation of minimum $20 \%$ capital in recessionary times and maximum $30 \%$ in good times); Miles, Yang \& Marcheggiano, supra note 81, at 2, 29 (positing that results of a model empirically estimating the benefit of reducing financial crises against the cost of increasing borrowing costs "suggest that the optimal amount of capital is likely to be around twice as great" as Basel III's capital requirements for largest banks of " just under $10 \%$ of risk-weighted assets," and further specifying a range of 16-20\%); see also Meilan Yan, Maximilian J.B. Hall \& Paul Turner, A Cost-Benefit Analysis of Basel III: Some Evidence from the UK 14 (Aug. 20, 2011) (unpublished manuscript), http://ssm.com/abstract=1913433 (suggesting that the optimal level of tangible common equity to risk-weighted assets for U.K. banks is $10 \%$, which is considerably higher than the Basel III target of $7 \%$ ).
}

88. Fed. DeP'T OF Fin., Swiss Confederation, Strengthening Financial SECTOR STABILITY, (2013), http://www.efd.admin.ch/themen/wirtschaft_waehrung/02315/.

89. We will return to this issue in Section IV.C, where we advance the use of national regulatory experimentation to get a better handle on the answer to that question. The previously mentioned models estimating optimal capital levels, Miles et al., supra note 81, and Yan et al., supra note 87 , are extremely sensitive to assumptions regarding the calculation of the costs and benefits of 
problematic to fix an optimal capital level is that the requisite amount (such as the amount determined as necessary for a bank to withstand a specified level of shock to assets at a specified probability of occurrence) changes with the nature of a bank's assets and liability structure, which themselves change over time, as a bank's business strategies, and relative asset values, change. ${ }^{90}$ And as new products are developed and business strategies change over time, any set of risk weights from which a capital requirement is set is bound to become outdated and inaccurate, lending themselves to regulatory arbitrage by which the bank's actions can undermine compliance with capital requirements. In short, the difficulty of making an optimal capital determination is exacerbated by the innovation that occurs in financial products, whose risk cannot be anticipated with confidence, in conjunction with the dynamic uncertainty of financial markets, in which new risks are created as banks respond in imperfectly predictable ways to capital regulation.

Although we do not have a firm conviction regarding how much above $10 \%$ capital requirements should be set, we do have a view on the form of the requirement. We favor pegging capital to the leverage ratio (i.e., to total assets independent of risk) over the risk-weighted capital approach that is at the core of Basel. In this we endorse the position advocated by two experienced bank regulators, Thomas Hoenig, Vice Chairman of the FDIC, and Andrew Haldane, Executive Director, Financial Stability of the Bank of England. They have both called for abandoning Basel III's complicated risk-weighted approach, favoring leverage ratios (and in Haldane's case, combining their use with return to simpler risk-weighted ratio calculations as well). ${ }^{91}$ Similarly, we contend that

raising capital levels, as are the models used by the Basel Committee to derive the G-SIB surcharge. BASEL COMM. ON BANKING SUPERVISION, supra note 76, at 17-19.

90. Charles W. Calomiris \& Richard J. Herring, Why and How to Design a Contingent Convertible Debt Requirement, in ROCKY TIMES: NEW PERSPECTIVES ON FINANCIAL STABILITY (Y. Fuchita et al. eds., 2012) . For a dynamic model of the appropriate leverage ratio (i.e., the level of capital changes as investment parameters change over time), and the contention that current, static capital requirements cannot provide a fully appropriate loss buffer, see Andrew W. Lo \& Thomas J. Brennan, Do Labyrinthine Legal Limits on Leverage Lessen the Likelihood of Losses? An Analytical Framework, 90 TEX. L. REV. 1775 (2012).

91. Vice Chairman Hoenig voted against the Basel III rule implementation as inadequate without a binding leverage constraint, Thomas Hoenig, Basel III Capital Interim Final Rule and Notice of Proposed Rulemaking, FDIC (July 9, 2013), https://www.fdic.gov/about/learn /board/hoenig/statement 7-9-2013.html, and has advocated that the United States take the lead and abandon Basel III in favor of the ratio of tangible equity (i.e., excluding goodwill, tax assets and other accounting entries) to tangible assets (assets less intangibles), Alan Zibel, FDIC's Hoenig: U.S. Should Reject Basel Accord, WALl ST. J., Sept. 14, 2012, http:/online.wsj.com/news/articles/SB100 00872396390443524904577651551643632924 . Haldane has called for simplifying Basel's capital requirements to eliminate IRB and reemphasize standardized weights for broad asset classes and for applying a stricter leverage ratio. Haldane, supra note 78; Andrew G. Haldane, Exec. Dir., Fin. Stability, Bank of Eng., The Dog and the Frisbee, Remarks at the Federal Reserve Bank of Kansas City's 366th Economic Policy Symposium (Aug. 31, 2012) (transcript available at http://www.bis.org/review/r120905a.pdf); see also Brooke Masters, Haldane Calls for Rethink of Basel III, FIN. TIMES, Aug. 31, 2012, http://www.ft.com/intl/cms/s/0/8a5e61b2-f34a-11 el-9c6c-00144feabd c0.html\#axzz3AW3T6ktn. For a cogent summary of both regulators' positions, see Alex J. Pollock, Hoenig and Haldane are Right About Basel III, AM. BANKER, Oct. 15, 2012, http://www.aei.org /article/economics/financial-services/banking/hoenig-and-haldane-are-right-about-basel-iii/. 
Basel's approach to capital needs to be recalibrated to emphasize the leverage ratio over the risk-weighted minimum, which would require a leverage ratio far higher than its present $3 \%$, which has been set as a backstop to the riskweighted ratio, rather than the mainstay of capital requirements.

Hoenig's and Haldane's emphasis on the leverage ratio over risk-weighted capital measurements is, in part, a reaction to Basel III's daunting complexity and obscurity. ${ }^{92}$ As Haldane has remarked, Basel III's multiple requirements and definitions of capital and risk-weight computations are so exceedingly complicated that they now reach over 600 pages, compared to Basel I's 30 page text, and for a large bank to comply it now requires several million calculations, as opposed to Basel I's single figures. ${ }^{93}$ These data suggest that it is, at present, all but impossible for any individual - investor, regulator, or bank executive - to get a good handle on the risk that such institutions are bearing.

Moreover, in our judgment, as the complexity of the risk-weight calculation has increased with each regulatory permutation, it magnifies what is a behavioral constant in the financial regulatory landscape: banks will game regulatory requirements to minimize the capital they must hold. It is axiomatic that the more complicated the system, the more leeway banks will have to engage in such activity, termed "regulatory arbitrage," reconfiguring their portfolios to achieve the maximum risk with the minimum amount of capital. In turn, the more room banks have to engage in such activity, the more difficult it becomes for regulators and investors to evaluate bank capital and monitor compliance.

The far simpler capital measure presented by a leverage ratio would cabin banks' ability to engage in complex manipulation across risk weights and assets to minimize their cost of capital. Importantly and relatedly, although it does not prevent gaming by increasing the risk of assets held, a leverage ratio requirement is easier for regulators and investors to monitor compliance, as well as to evaluate banks' relative risk, as it will increase the comparability of banks' risk and performance compared to the IRB approach. This would have a beneficial feedback effect on bank managers' incentives to take risks, as better informed investors and regulators better convey their preferences regarding risk. Moreover, in the financial crisis, leverage ratios, and not Basel riskweighted capital, were associated with better stock performance, indicating that investors perceive the leverage ratio as a superior indicator of the future risk of a bank's portfolio. ${ }^{94}$ Accordingly, in our judgment, a substantially higher Intended Illusion, Remarks at the International Association of Deposit Insurers 2013 Research Conference (Apr. 9, 2013) (transcript available at http://www.fdic.gov/news/news/speeches/spapr 0913.html).

93. Haldane, supra note 91, at 6-7.

94. Asli Demirguc-Kunt, Enrica Detragiache \& Ouarda Merrouche, Bank Capital: Lessons from the Financial Crisis 10 (IMF Working Paper No. 10/286, 2010). 
capital requirement in the form of a leverage ratio is the regulatory reform most consonant with advancing the Restricted Equity proposal's objective to reduce excessive risk-taking of banks.

\section{B. Requiring Capital in the Form of Contingent Convertible Debt}

An alternative to raising capital requirements as the capital structure reform to couple with the Restricted Equity proposal is to mandate a substantial issuance of CoCos. In the wake of the global financial crisis, $\mathrm{CoCos}$ have been the focus of increasing interest to bank regulators as they are thought by many to be an efficacious means of capitalizing banks: there is a lower upfront cost, compared to a straight equity issue, in using CoCos because the initial issue, as a debt security, will have a lower cost of capital. ${ }^{95}$ CoCos are not merely a theoretical concept: Swiss banks have sold such securities, as the Swiss banking authorities, concurrently with dramatically increasing capital requirements to $19 \%$, permitted the instruments to qualify as capital (up to $9 \%)^{96}$

For CoCos to be an effective mechanism to complement the Restricted Equity proposal, they must be structured so as to incentivize managers to issue

95.

See, e.g., CALOMIRIS \& HERRING, supra note 90. Calomiris and Herring identify three objectives of CoCo proposals, the choice of which affects the instruments' design: (1) providing a contingent cushion of equity capital to reduce the need for a government bailout upon a triggering event; (2) providing a credible signal of default risk in the yield spread on the CoCo so that regulators can take action before it is too late; and (3) incentivizing management to increase equity capital voluntarily in order to avoid the highly dilutive action of a CoCo conversion. Id. at 11. Admati et al., supra note 87, contend that equity capital should not cost more than debt capital, citing the Modigliani and Miller ("MM") theorem of the irrelevance of firm capital structure to firm value that maintains that by decreasing debt in the capital structure, equity will be less risky (and hence less costly), in the absence of market frictions. Id. at 17-18. There is, however, reason to believe that frictions in the banking context limit the applicability of $\mathrm{MM}$ and that the cost of issuing significantly more equity would be expensive. These frictions include most importantly a liquidity premium that investors pay for the unique characteristic of banks' short-term liabilities, "information acquisition insensitivity" (i.e., investors can trade the security with no need to ask questions nor incentive to produce private information about its value), see, for example, Tri Vi Dang, Gary Gorton \& Bengt Holmstrom, Ignorance, Debt and Financial Crises (Feb. 13, 2012) (unpublished manuscript), http://faculty.som.yale.edu/ garygorton/working_papers.html, in addition to information asymmetries, agency costs and the tax subsidy of debt, which Calomiris and Herring emphasize for favoring CoCos. CALOMIRIS \& HERRING, supra note 90, at 8-9. And there can be a significant cost to the real economy when banks' cost of capital increases, as banks can respond by curtailing lending, rather than increasing their equity capital. See, e.g., ld. at 8 (providing sources documenting contractionary impact on lending of equity capital shocks); MACROECONOMIC ASSESSMENT GRP. BANK FOR INT'L SETTLEMENTS, FINAL REPORT: ASSESSING THE MACROECONOMIC IMPACT OF THE TRANSITION TO STRONGER CAPITAL AND LIQUIDITY REQUIREMENTS 3-5 (2010), http://www.bis.org/publ/othp12.pdf (estimating impact on lending and GDP of Basel III increased capital requirements). These data should not be interpreted to mean that bank equity levels should not be increased. Rather, they indicate that there is a cost-benefit tradeoff in adopting such a policy, which provides impetus to consideration of the use of CoCos as an alternative.

96. Credit Suisse Goes CoCo to Placate Critics, SwISsnFo.ch (July 18, 2012), http://www.swissinfo.ch/eng/business/Credit_Suisse_goes_CoCo_to_placate_critics.html?cid=3313099 4. The Swiss banking authority's higher minimum capital requirement was immediately imposed, and of the $19 \%, 10 \%$ must be common stock while the remainder can be financed by CoCos. Swiss Banks Set to Issue CoCo Bonds in Large Size, CREDITFLUX (Oct. 4, 2010), http://www.creditflux.com/Investing/2010-10-04/Swiss-banks-set-to-issue-coco-bonds-in-large-size/. 
equity to avoid triggering conversion (or to engage in sufficiently conservative business strategies or prudential risk management so as not to come close to the realm in which the CoCos would be triggered). Upon such action, the bank would be positioned with a sufficiently high level of capital so that it would remain at a considerable distance from the insolvency zone in which the moral hazard or agency cost of debt problem can induce excessive risk-taking. In this scenario, use of the contingent debt instrument would achieve the same objective as mandating higher capital levels from the outset. The characteristics of CoCos that would be appropriate for this purpose have been elaborated by Charles Calomiris and Richard Herring: a large CoCo issue, a credible trigger that is based on observable market prices at a high ratio of equity to assets (so that the trigger would occur long before the bank is near insolvency), and a conversion ratio sufficiently dilutive of the common stock that it makes the dilution from issuing equity instead of undergoing the debt's conversion a more desirable course of action by management. ${ }^{97}$ Getting the conversion dilution factor correct is critical because it avoids what has been called the "Fuld" or "Lehman Brothers" problem, which the Restricted Equity proposal could magnify: the problem that a CEO with a sizeable stockholding will not want to issue common stock, which would put a potentially distressed bank on a sound footing, because the issuance would dilute his interest (that is, devalue the shares) ${ }^{98}$ Such a CEO might not take prompt action until it was too late to issue any equity, for instance, so that the action then resorted to might be the type of high-risk gamble that is induced by limited liability in the insolvency zone.

Figure 2 provides a stylized depiction of a large bank's capital structure under the three scenarios we have discussed: existing capital requirements, and the two alternative capital structure reforms to couple with the Restricted Equity proposal, a substantially higher leverage ratio, and a sizeable CoCo mandate. As depicted in the figure, a properly designed $\mathrm{CoCo}$, in conjunction with a solid equity base, can replicate the capital structure attained by a higher capital requirement. ${ }^{99}$ This suggests the Restricted Equity proposal could also

97. CALOMIRIS \& HERRING, supra note 90, at 12 . They recommend an issue size proportional to the bank's equity, and a market-based trigger based on a 90 -day moving average of the ratio of the market value of equity to the sum of the market value of equity plus the face value of debt, and a conversion dilution of $5 \%$ of the market value of the stock relative to face value. In addition to selling stock to avoid conversion, a bank could also sell assets to maintain the requisite equity to asset ratio.

98. This problem, referred to as the problem of "debt overhang" preventing equity issuance, is actually long-recognized in the finance literature. It was first identified by Stewart Myers in his 1984 article, The Capital Structure Puzzle. Stewart C. Myers, The Capital Structure Puzzle, 39 J. FIN. 575 (1984).

99. We would still increase the equity capital requirement to be greater than the Basel requirements in the CoCo alternative; it just would not need to be as high because of either the availability of the CoCos to convert into equity should the adverse state occur or the fact that management will preemptively issue equity building up the capital ratio sufficiently high to avoid triggering conversion. Calomiris and Herring suggest a $10 \%$ capital requirement in conjunction with a $10 \%$ minimum amount of CoCos. CALOMIRIS \& HERRING, supra note 90, at 22. 
be tied to a CoCo requirement to preserve its desirable incentive effect on bank risk-taking.

Of course, the efficacy of CoCos depends crucially on the proper structuring of the CoCos and initial capital levels. This includes the size of the CoCo issue, the definition of the conversion trigger, the conversion rate, and operational details such as whether all CoCos must be converted upon a triggering event, and whether upon conversion, new CoCos must be issued. Indeed, as proponents of CoCos are well aware, any one of many possible design flaws could undermine the effectiveness of the instrument, particularly a poorly calibrated trigger (such as an accounting-based trigger which might not capture the true financial condition of the bank or a stock market trigger that could be attacked by short sellers creating a "death spiral" of a declining price). The most sophisticated proposals are structured to avoid the most obvious pitfalls in trigger selection. ${ }^{100}$

It is, we think, therefore fair to say that formulating an effective CoCo requirement will be challenging for a regulator to get just right, and the diversity of proposals in the literature, none of which have been replicated in the instruments that have actually been issued, only add to regulatory perplexity, as they make clear that there is considerable disagreement over optimal design. ${ }^{101}$ In this regard, the requirement of a higher capital requirement is a much simpler regulatory solution to the capital structure reform issue presented by the limitation on the Restricted Equity proposal when a bank nears insolvency. There are simply fewer moving parts that a regulator must evaluate. We therefore tend to prefer that approach, although we are not averse to experimentation across nations on any of these dimensions.

\section{Introducing Diversity and Experimentation into Financial Regulation}

The Basel accord that is the cornerstone of international financial regulation is premised upon harmonizing capital and supervisory regulations worldwide. As we have noted, the ideal capital requirements, or CoCo configurations, are not matters readily ascertainable. Yet when all nations are prompted to adopt identical regulations, there is no room for learning what regulations among the plausible might work better. Moreover, the dynamic environment in which financial institutions operate can quickly render regulations inapt (as firms adapt and innovate to get around requirements and minimize capital costs while new interactions or risks arise that regulations did

100. See e.g., Robert L. McDonald, Contingent Capital with a Dual Price Trigger (February 15, 2010) (unpublished manuscript), http://ssm.com/abstract=1553430 (discussing tradeoffs involved in any CoCo design and advocating a specific market-based trigger as presenting best tradeoff of advantages and problems with CoCos); DUFFIE, supra note 80, at 48-50 (noting problems with accounting- and simple market-based triggers, and suggesting alternative market-based triggers of a trailing average of stock prices or credit default swap prices to avoid them).

101. As we maintain in Section IV.C, use of national regulatory experimentation would assist in determining an effective CoCo design, as well as an optimal capital ratio. 
not anticipate), yet the accord's revision process is cumbersome and incapable of nimble responses. Negotiations over changes to the accord tend to be intense and extended, as nations vie for provisions that will advantage, or at least not disadvantage, domestic financial institutions, and that are consistent with national policies. And when, due to exigency, as in the recent financial crisis, the negotiation proceeds more rapidly, it is undercut by being offset with an extremely long transition period.

We therefore believe that there is a need to introduce regulatory diversity and experimentation into international financial regulation, to generate information about what regulatory approaches are most cost-effective in maintaining banks' equity positions. This can be done within the Basel architecture, by establishing a peer review process in which nations would receive approval to deviate from Basel requirements. The standard for approval would be a determination by the review committee that the proposed deviation would not significantly increase global systemic risk. To ensure further that a departure would not adversely affect global systemic risk, approved departures would be subject to both ongoing monitoring and a periodic review postapproval process to evaluate the impact of its implementation on global systemic risk. $^{102}$

It is true that some nations have imposed more stringent requirements than those adopted in Basel III. But we do not think this action is sufficient to obviate the need for a formal process permitting deviations. Although the Basel requirements are stated as minimums, so the present actions will not be sanctioned by the Basel Committee, ${ }^{103}$ it must be noted that it has historically been rare for nations to deviate from Basel requirements and in the European Union ("EU") there has been disagreement over whether a member-state should be permitted to deviate from the EU's implementation of Basel standards at all. ${ }^{104}$ More important, Basel does not permit experimentation in the form of its

102.

For a comprehensive analysis of the construction and implementation of a diversity mechanism within the Basel regulatory architecture, see Roberta Romano, For Diversity in the International Regulation of Financial Institutions: Critiquing and Recalibrating the Basel Architecture, 31 YALE. J. REG. 1 (2014). The requisite impact analysis is certainly feasible: economic analyses, using a variety of methodologies, are routinely undertaken by bank regulators to assess the impact of regulatory changes, such as, increasing capital requirements, on financial system stability as well as on the real economy. Although even the best of methodologies is imperfect, they are sufficient for the task, and the post-approval review and monitoring will both generate additional information to improve the impact analysis and provide a safety valve to exit the experiment if, contrary to analytical predictions, it tums out badly.

103. See Id. at 72-73, nn. 121-123. The identity of the deviators no doubt also matters: when it is a critical player in global financial regulation that has influence on the Basel Committee's decisions, (such as, the United States), it is not probable that the Committee would object to the action.

104. The United Kingdom objected to the EU's proposed implementation of Basel III, which would not even permit member states to deviate by increasing capital requirements. E.g., Nikki Tait, EU Leads Pack on Bank Capital, FIN. TIMES, July 20, 2011, http://www.ft.com/int l/cms/s/0/3fb4l c06-b2e1-11 e0-86b8-00144feabdc0.html\#axzz3AW3T6ktn. The final rule permitted member states to impose stricter requirements for two years, extendable upon the approval of the European Council, and gave a "qualified majority" of the Council the right to reject a 
capital requirements, which would allow the abandoning of risk-weighted capital for alternative regimes, such as a leverage ratio bolstered with a subordinated debt or CoCo regime. ${ }^{105}$ In our view, adopting a mechanism to introduce diversity into international financial regulation will facilitate nations' experimentation with capital levels, and other regulatory instruments, the comparative effects of which should provide valuable information to regulators concerning which approaches work best.

\section{Conclusion}

In the wake of the global financial crisis, attention has often focused on whether incentives generated by bank executives' compensation programs led to excessive risk-taking. Post-crisis compensation reform proposals have taken broadly three approaches: long-term deferred equity incentive compensation, mandatory bonus clawbacks upon accounting restatements and financial losses, and debt-based compensation. We contend that bank executives', significant employees', and directors' incentive compensation should consist only of restricted stock and restricted stock options-restricted in the sense that the individual cannot sell the shares or exercise the options for two to four years after his or her last day in office. In our judgment, such an incentive compensation package will focus bank managers' attention on the long-run and discourage them from investing in high-risk but value-destroying projects.

As banks' equity values approach zero, equity based incentive programs such as our Restricted Equity proposal, may lose their effectiveness in restricting managers from taking on excessive risk and acting to maximize shareholders' long-term value. Hence, for equity-based incentive structures to be effective, banks should be financed with considerably more equity than they are currently financed, so as to reduce the probability that a bank's equity value approaches zero, although we do not have a precise number to recommend. We advocate two alternatives to achieve this objective, requiring either substantially higher leverage ratios (the percentage of equity to total assets) or issuance of a sizeable level of contingent convertible debt or CoCos (debt that converts to equity under specified circumstances). We further recommend introducing regulatory diversity and experimentation into the international financial architecture, as a mechanism to generate information concerning the most efficacious design of bank capital structure reforms, and thereby improve the quality of regulatory decision-making.

nation's proposal of stricter measures. Press Release, Council of the European Union, Council Adopts New Bank Capital Requirements (June 20, 2013), www.consilium.europa.eu/.

105. For an example of such a proposal being advanced as preferable to adoption of the then newly-proposed Basel II regime of internal-ratings based risk-weighted capital requirements, see Shadow Financial Regulatory Committee, Statement No. 160: Reforming Bank Capital Regulation, AEI.ORG (March 2, 2000), http://www.aei.org/article/economics/financial-services/reforming-bankcapital-regulation-article. 


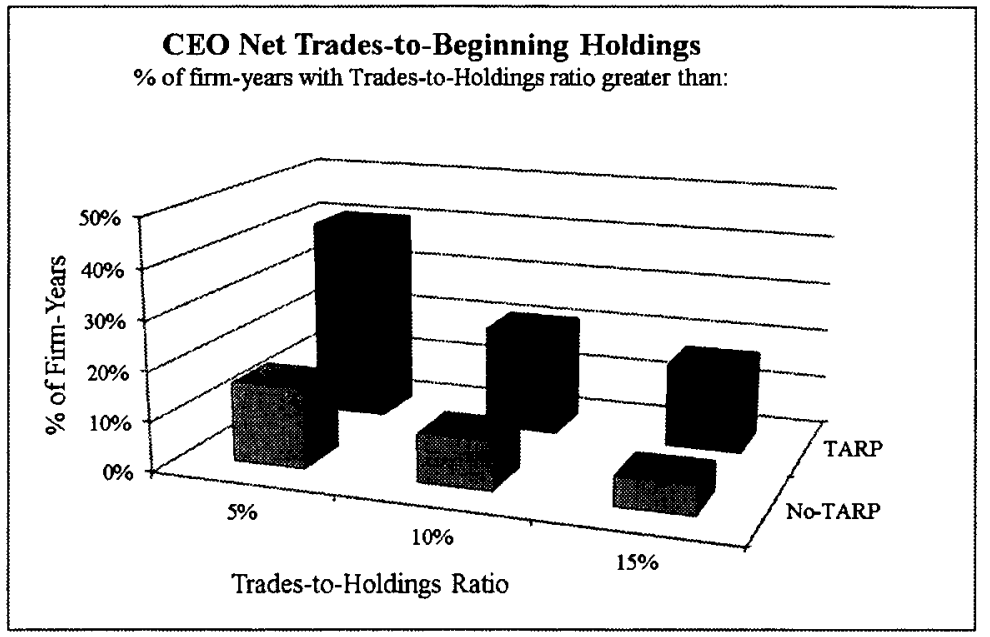

Figure 1: Ratio of Bank CEOs' Net Trades-to-Beginning Holdings 2000-08.

This figure, derived from data in Sanjai Bhagat and Brian Bolton, Financial Crises and Bank Executive Incentive Compensation, 25 J. Corp. Fin. 313 (2014), shows the histogram distribution of the percentage of firm years, over the time period 2000-08, within two samples of bank CEOs, those of 14 firms that received TARP funds ("TARP") and those of 37 banks which were not TARP recipients ("NoTARP"), when the ratio of the CEOs' net trades, calculated as all open market sales of stock less open market purchases and cost of exercising options, to the CEO's stock holdings, including beneficial ownership and vested stock and exercisable options, at the beginning of the year, exceeded $5 \%, 10 \%$ or $15 \%$.
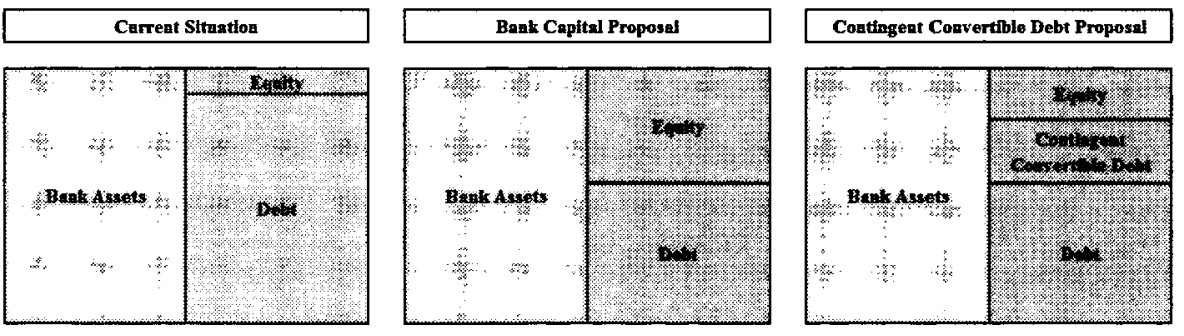

\section{Figure 2: Balance Sheet of a Large Bank}

This figure presents stylized depictions of a large bank's capital structure under three scenarios: existing capital regulations and the two alternative capital structure reforms discussed in the text to couple with the Restricted Equity incentive compensation proposal: higher bank capital requirements and contingent convertible debt securities issuance. 